\title{
Review Article \\ Enhancing the Health-Promoting Effects of Tomato Fruit for Biofortified Food
}

\author{
Assunta Raiola, Maria Manuela Rigano, Roberta Calafiore, \\ Luigi Frusciante, and Amalia Barone \\ Department of Agricultural Sciences, University of Naples "Federico II", Via Università 100, Portici, 80055 Naples, Italy \\ Correspondence should be addressed to Amalia Barone; ambarone@unina.it
}

Received 13 December 2013; Accepted 1 February 2014; Published 12 March 2014

Academic Editor: Laura Di Renzo

Copyright (C) 2014 Assunta Raiola et al. This is an open access article distributed under the Creative Commons Attribution License, which permits unrestricted use, distribution, and reproduction in any medium, provided the original work is properly cited.

Consumption of tomato fruits, like those of many other plant species that are part of the human diet, is considered to be associated with several positive effects on health. Indeed, tomato fruits are an important source of bioactive compounds with known beneficial effects including vitamins, antioxidants, and anticancer substances. In particular, antioxidant metabolites are a group of vitamins, carotenoids, phenolic compounds, and phenolic acid that can provide effective protection by neutralizing free radicals, which are unstable molecules linked to the development of a number of degenerative diseases and conditions. In this review, we will summarize the recent progress on tomatoes nutritional importance and mechanisms of action of different phytochemicals against inflammation processes and prevention of chronic noncommunicable diseases (e.g., obesity, diabetes, coronary heart disease, and hypertension). In addition, we will summarize the significant progress recently made to improve the nutritional quality of tomato fruits through metabolic engineering and/or breeding.

\section{Introduction}

The tomato belongs to the Solanaceae family that includes more than 3,000 species. In particular, the section of the Lycopersicon genus Solanum consists of 13 species or subspecies: the cultivated tomato, Solanum lycopersicum, which is the only domesticated species, and 12 wild species (such as S. chmielewskii, S. habrochaites, S. pennellii, and S. pimpinellifolium). Tomato fruits are an important source of nourishment for the whole world's population. Its world production is estimated to be around 159 million tons, while the average annual fresh tomato consumption is $18 \mathrm{~kg}$ per European and $8 \mathrm{~kg}$ per capita in the US [1]. In the last few years, tomato consumption has further increased since tomato fruits supply both fresh market and processing products such as soups, juices, purees, and sauces. The Economic Research Service of the USDA estimates that 35\% of raw tomatoes are processed into sauces, $18 \%$ into tomato paste, $17 \%$ into canned tomatoes, $15 \%$ into juices, and $15 \%$ into catsup [2]. The tomato fruits, like those of many other plant species that are part of our diet, are an important source of substances with known beneficial effects on health, including vitamins, minerals, and antioxidants [3]. Indeed, tomato fruit consumption has been associated with a reduced risk of inflammatory processes, cancer, and chronic noncommunicable diseases (CNCD) including cardiovascular diseases (CVD) such as coronary heart disease, hypertension, diabetes, and obesity [2]. Antioxidant metabolites are a group of vitamins, carotenoids, phenolic compounds, and phenolic acid, with health-enhancing effects on our body $[2,3]$. The total antioxidant activity of tomato fruits is commonly classified into hydrophilic and lipophilic ones. The first is conferred mainly by soluble phenolic compounds and vitamin $\mathrm{C}$ and shows a significant impact on total antioxidant activity (83\%), while the latter is conferred by carotenoids, vitamin E, and lipophilic phenols (17\%) [4]. Many factors such as genetics (cultivar or variety), environment (light, temperature, mineral nutrition, and air composition), and cultural practices (ripening stage at harvest and irrigation system) affect the chemical composition of tomatoes $[5,6]$. In this paper, a global point on tomatoes nutritional importance and mechanisms of action of different phytochemicals against inflammation processes according to the last discoveries is discussed. 
Recently, significant progresses have been made in order to improve the levels of human health promoting compounds in tomato fruits through metabolic engineering and/or breeding $[7,8]$. However, breeding work is complicated by the complex nature of many of these characters, which often requires quantitative genetic approaches for the identification of genes and QTLs (quantitative trait loci) involved in their regulation [9]. In fact, the synthesis of many of the compounds responsible for the tomato nutritional quality is the result of coordinated activities that involve many of the primary and secondary metabolism pathways regulated by developmental, physiological, and environmental signals.

Therefore, in this paper, we will summarize the recent progress made to improve the nutritional quality of tomato fruits according to current state of the art.

\section{Bioactive Tomato Compounds}

Regular consumption of tomato fruit and its products is associated with lower risk of CNCD and several types of cancer and inflammation because of interaction of phytochemicals with metabolic pathways that are related to inflammatory response and oxidative stress.

Some evidences support a role for tomato products in the prevention of lipid peroxidation that is a risk factor of atherosclerosis and cardiovascular disease [10].

High dietary intake of tomato products can reduce LDL cholesterol levels and increase LDL resistance to oxidation [11]. In addition, Burton-Freeman et al. [12] reported that tomato consumption during a meal attenuated postprandial lipemia-induced oxidative stress and associated inflammatory response. An important role of tomatoes has been also attributed to the conservation of DNA stability. Daily intake of a tomato drink called Lyc-O-Mato significantly reduced (by about 42\%) DNA damage in lymphocytes subjected to oxidative stress [13]. These effects are related to the presence of several phytochemicals in raw tomatoes and their products. Table 1 shows the general effects of tomato bioactive compounds on health, while Table 2 summarizes the main evidences about anti-inflammatory and antioxidant activities.

2.1. Carotenoids. Carotenoids are tetraterpenes belonging to fat-soluble pigments. They include provitamin A carotenoids, such as $\beta$-carotene and $\beta$-cryptoxanthin, and non-provitamin A carotenoids, such as lutein and lycopene. They contribute to the photosynthetic machinery in plants and protect them against photo damage [67]. More than 600 carotenoids were identified in nature, among which around 40 are present in food normally included in human diet. [68]. Geographical location has a great impact on carotenoid content and bioaccessibility. For example, carotenoid content of various tomato varieties grown in Ireland differed from those grown in Spain [69].

Several studies have reported the health benefits of carotenoids related to their antioxidant power, such as immune system stimulation and antitumor activity $[18,45$, 70]. Dietary supplements of carotenoids may act as moderate hypocholesterolemic agents, as a consequence of their inhibitory effect on macrophage 3-hydroxy-3-methyl glutaryl coenzyme A (HMGCoA) reductase, the rate-limiting enzyme in cholesterol synthesis [71]. Carotenoids cause changes in the expression of many proteins participating in cell proliferation and signaling pathways. For example, lycopene is associated with reduction of cyclin D1 protein, a known oncogene overexpressed in many primary tumors. In addition, lycopene can increase expression of several differentiation-related proteins, such as cell surface antigen (CD14), oxygen burst oxidase, and chemotactic peptide receptors [72]. According to scientific evidences, the carotenoid intake from tomatoes is the most important nutritional contribution of this fruit, and therefore, the highest weight in the index of antioxidant nutritional quality is attributed to carotenoids content $[3]$.

2.1.1. Lycopene. Tomatoes contain $8-40 \mu \mathrm{g}$ per gram fresh weight of lycopene, about $80 \%$ of total dietary intake of this carotenoid $[73,74]$. Field-grown tomatoes appear to contain higher levels of lycopene, ranging from 5.2 to $23.6 \mathrm{mg} / 100 \mathrm{~g}$ fresh weight (FW) than greenhouse-grown tomatoes ( 0.1 and $10.8 \mathrm{mg} / 100 \mathrm{~g} \mathrm{FW}$ ) [75]. Accumulation during fruit ripening results from the downregulation of the lycopene cyclase gene $(C r t L)$, a gene conserved through evolution from the time of cyanogenic bacteria [76]. Lycopene is a polyunsatured molecule containing 13 double bonds that can exist in transand cis-configurations [77]. In fresh tomatoes, lycopene is mainly found in trans-conformation, while thermal treatments, light, acids, oxygen, and digestion can cause transformation into the more bioactive cis-form [78]. Lycopene is the main phytochemical in tomato fruits for its strong antioxidative role associated with its ability to act as free radical scavengers from reactive oxygen species (ROS), generated by partial reduction of oxygen [79]. Furthermore reactive nitrogen species (RNS) can be produced. ROS and RNS include free radicals and other nonradical reactive derivatives also called oxidants [80]. They are produced either from normal cell metabolisms in situ or from external sources (pollution, radiation, and cigarette smoke). Radical accumulation in the body generates a phenomenon called oxidative stress that results from an imbalance between formation and neutralization of ROS/RNS in cells [81]. One of the most undesirable effects of ROS is lipid peroxidation with consequent formation of radicals. The products formed during these mechanisms are toxic. In particular malondialdehyde can cause mutagenic lesions [82]. These processes play a major role in the aging and development of chronic and degenerative illness such as cancer, atherosclerosis, autoimmune disorders, cataract, rheumatoid arthritis, and neurodegenerative and cardiovascular diseases. Lycopene can transform the high reactive free electron on DNA to a more stable free radical by delocalization along its conjugate 13 double bonds.

ROS can activate the transcription nuclear factor kappa B $(\mathrm{NFkB})$ that gives rise to the expression of genes of pro- and 
TABLE 1: Effects of bioactive compounds occurring in tomato.

\begin{tabular}{|c|c|c|c|}
\hline Class & Compound & Main effects & References \\
\hline \multirow{7}{*}{ Carotenoids } & \multirow[t]{2}{*}{ Lycopene } & $\begin{array}{l}\text { Control of oxidative stress and inflammation (production of IL-10 and inhibition of } \\
\text { IL- } 6 \text { and IL-8) }\end{array}$ & [14-17] \\
\hline & & $\begin{array}{l}\text { Cancer inhibition (prostate, breast, colorectal, endometrial, lung, oral, and } \\
\text { pancreatic) }\end{array}$ & {$[18,19]$} \\
\hline & \multirow{2}{*}{$\beta$-Carotene } & Prevention of photooxidative damage & {$[20]$} \\
\hline & & Inhibition of atherosclerosis and prevention of myocardial infarction & {$[21]$} \\
\hline & \multirow{3}{*}{ Lutein } & Preservation of eye health and improvement of symptoms in ARMD & {$[22,23]$} \\
\hline & & Protection against cardiovascular diseases (inhibition of NF- $\kappa$ B signaling) & {$[24,25]$} \\
\hline & & Increasing of DNA resistance to endogenous damage and repair & {$[26]$} \\
\hline \multirow{7}{*}{ Vitamins } & \multirow{2}{*}{ Vitamin E } & Inhibition of lipid peroxidation and cardiovascular diseases & {$[27,28]$} \\
\hline & & Decreasing risks of type 2 diabetes and advanced prostate cancer & {$[29,30]$} \\
\hline & \multirow{2}{*}{ Vitamin C } & Inhibition of LDL oxidation and monocyte adhesion & {$[31,32]$} \\
\hline & & Decreasing of total cholesterol and CRP & {$[33]$} \\
\hline & \multirow{3}{*}{ Folates } & $\begin{array}{l}\text { Prevention of megaloblastic anemia in pregnant women and regulation of fetal } \\
\text { growth }\end{array}$ & [34] \\
\hline & & Control of homocysteine metabolism & {$[35]$} \\
\hline & & Reduction in the rate of neural tube defects & {$[36]$} \\
\hline \multirow{6}{*}{ Phenolic compounds } & \multirow{3}{*}{ Flavonoids } & Intestinal anti-inflammatory activity & {$[37]$} \\
\hline & & Inhibition of TNF $\alpha$-induced inflammation & {$[38]$} \\
\hline & & Prevention of gastric cancer risk & {$[39,40]$} \\
\hline & Phenolic acids & $\begin{array}{l}\text { Protection against DNA oxidation and antitumor activity against colon } \\
\text { carcinogenesis }\end{array}$ & {$[41,42]$} \\
\hline & \multirow{2}{*}{ Tannins } & Inhibition of adipogenesis & {$[43]$} \\
\hline & & Antibacterial, antiviral, anticarcinogenic, and cardiovascular action & {$[44]$} \\
\hline
\end{tabular}

anti-inflammatory cytokines and their subsequent production [83]. It is demonstrated that lycopene inhibits this activation $[14,15]$. Anti-inflammatory cytokines such as IL-10 are produced to control inflammation, while proinflammatory cytokines including tumor necrosis factor-alpha (TNF- $\alpha$ ), IL6 , and IL- 8 increased the inflammatory response. Lycopene stimulates the first one and inhibits the latter in macrophages and adipocytes [84]. Doses of $10 \mathrm{mg}$ lycopene/day administered for 3 months decreased PSA (Prostate Specific Antigen) level, tumor grade, bone pain, and urinary tract symptoms in patients with metastatic prostate cancer [19], interfering with growth factor receptor signaling and cell cycle progression [85]. In addition, lycopene can inhibit other cancer types (breast, colorectal, endometrial, lung, oral, and pancreatic) [18]. Nevertheless, according to some studies, lycopene is not potent enough to be clinically useful as a drug for prostate cancer because high concentrations (above $1 \mu \mathrm{mol} / \mathrm{L}$ ) are needed to achieve significant response in humans [8688 ]. In presence of diseases such as cancer and cardiovascular diseases, higher levels of lycopene ranging from 35 to $75 \mathrm{mg}$ per day may be required [89]. Lycopene can modulate cyclooxygenase pathways and xenobiotic metabolism because $\beta$-carotene and lycopene supplementation interact with the metabolism of linoleic acid, resulting in either an increase ( $\beta$-carotene) or decrease (lycopene) in plasma concentration [71]. An 83\% reduction in prostate cancer risk was observed in a group of men enrolled in the Physician's
Health Study, with the highest plasma lycopene concentration $(0.40 \mu \mathrm{m} / \mathrm{L})$ in comparison with the lowest lycopene group $(0.18 \mu \mathrm{m} / \mathrm{L})[90]$.

Many chronic diseases and increasing of mortality are directly related to the global obesity epidemic (body mass index $\geq 30 \mathrm{~kg} / \mathrm{m}^{2}$ ), which started in the 1980s. Adolescent populations are currently the group mainly exposed to risk of obesity [91]. Serum concentrations of C-reactive protein (CRP), tumor necrosis factor (TNF- $\alpha$ ), and interleukin (IL)6 are significantly correlated with weight, body mass index (BMI), and waist circumference [92]. These aspects assume a major importance considering that a link between skeletal muscle and adipose tissue has been reported and related with the control of body weight, muscle mass, and fat mass. In particular interleukin (IL)-15 and TNF- $\alpha$ play an important role in crosstalk between adipose tissue and skeletal muscle [93].

IL- 6 and TNF- $\alpha$ contribute to liver production of CRP and atherosclerosis by inducing insulin resistance and upregulating the expression of other inflammatory mediators. Di Renzo et al. [94] reported that, in Italian Caucasian females, the fat mass percentage (FM\%) is a main factor of an increase in IL-6 production and insulin resistance. In particular, $-174 \mathrm{G} / \mathrm{C}$ polymorphism in IL-6 promoter has been recognized as a marker which could contribute to identify vulnerable individuals at risk of age and obesityrelated diseases. 
TABLE 2: Main anti-inflammatory and antioxidant effects of bioactive tomato compounds.

\begin{tabular}{|c|c|c|}
\hline & Compound & References \\
\hline \multirow{13}{*}{$\begin{array}{l}\text { Anti- } \\
\text { inflammatory } \\
\text { effect }\end{array}$} & Lycopene & {$[14,16,17]$} \\
\hline & $\beta$-Carotene & {$[45]$} \\
\hline & Lutein & {$[46,47]$} \\
\hline & Vitamin E & [17] \\
\hline & Vitamin C & {$[33]$} \\
\hline & Rutin & {$[48-51]$} \\
\hline & Quercetin & {$[48,49,52]$} \\
\hline & Glycosides of quercetin & {$[53]$} \\
\hline & Catechin & {$[50]$} \\
\hline & Resveratrol & {$[37,54,55]$} \\
\hline & C3G (cyanidin 3-glucoside) & {$[56,57]$} \\
\hline & Phenolic acids & {$[58]$} \\
\hline & Tannins & {$[44]$} \\
\hline \multirow{11}{*}{$\begin{array}{l}\text { Antioxidant } \\
\text { effect }\end{array}$} & Lycopene & {$[15,59]$} \\
\hline & $\beta$-Carotene & {$[20,59]$} \\
\hline & Lutein & {$[46]$} \\
\hline & Vitamin E & {$[27,28,60]$} \\
\hline & Vitamin C & {$[31,32]$} \\
\hline & Polyphenols & {$[58]$} \\
\hline & Quercetin & {$[61]$} \\
\hline & C3G (cyanidin 3-glucoside) & {$[40]$} \\
\hline & Phenolic acids & {$[41,62-64]$} \\
\hline & Cinnamic acids (1,5-dicaffeoylquinic) & {$[65]$} \\
\hline & Tannins & {$[66]$} \\
\hline
\end{tabular}

There is now strong evidence for the benefits of tomatoes in terms of protection against diseases associated with metabolic syndrome and obesity.

In particular, lycopene reduces transcript levels of proinflammatory cytokines with downregulation of IL- 6 expression [16, 17]. Markovits et al. [16] reported the effect of tomato-derived lycopene consumption on markers of inflammation and oxidative stress in a group of patients with extreme obesity. Obese patients showed abnormally higher markers of inflammation and oxidation products and lower plasma carotenoids compared to control subjects ( 0.54 versus $0.87 \mu \mathrm{g} / \mathrm{mL}$ ). Following lycopene treatment, a significant elevation of plasma carotenoids, specifically lycopene, occurred in the treatment versus the placebo group. Kuopio Ischemic Heart Disease Risk Factor Study examined the relation between serum antioxidant and intima-mediated thickness of the common carotid artery, a marker related to the risk of having an acute coronary event. Lower levels of plasma lycopene were showed in men who had a coronary event compared with men who did not [17]. Several studies demonstrated that anti-inflammatory effects derived by tomato products consumption were superior to that of lycopene delivered as a single compound $[27,95]$.
2.1.2. $\beta$-Carotene. $\beta$-Carotene is considered a provitamin because it can be converted into retinol, a compound essential for vision. It is known as a strong antioxidant and the best quencher of singlet oxygen. At low partial pressures of oxygen, such as those found in most tissues under physiological conditions, $\beta$-carotene was found to inhibit oxidation. In tomatoes grown in a field located in the S. Marzano area, reported values were between 0.28 and $1 \mathrm{mg} / 100 \mathrm{~g} \mathrm{FW}$ [3]. These levels were in accordance with other studies $[96,97]$. In commercial cherry tomato varieties, $\beta$-carotene amount reached $1.2 \mathrm{mg} / 100 \mathrm{gr}$ FW [98]. Bioaccessibility of $\beta$ carotene from raw tomatoes was reported to be about $0.1 \%$ [99].

A study found that both $\beta$-carotene and lycopene $(2.5 \mathrm{mmol} / \mathrm{L}, 2 \mathrm{~h})$ totally abolished TNF- $\alpha$-induced ROS levels $(1 \mathrm{ng} / \mathrm{mL}, 16 \mathrm{~h})$ in TNF- $\alpha$-treated human umbilical vein endothelial cells. This was due to the redox balance protection and to the maintenance of nitric oxide (NO) bioavailability [59]. Several studies demonstrated that $\beta$-carotene prevents photooxidative damage and sunburn showing photoprotection in humans. Erythema formation was significantly diminished when $\beta$-carotene was applied on human skin or with a dietary intervention alone or in combination with $\alpha$-tocopherol for 12 weeks [20]. Metabolites derived from all-trans- $\beta$-carotene inhibit atherosclerosis in hypercholesterolemic rabbits. This could be due to stereospecific interactions with retinoic acid receptors in the artery wall [100].

Recently, Karppi et al. [21] found that low concentrations of serum $\beta$-carotene may be associated with an increased risk of CHF (congestive heart failure) and cardiac death in men.

However, some studies do not support the absolute favorable role of $\beta$-carotene assumption. The initial antioxidant activity of $\beta$-carotene is followed by a prooxidant action at high oxygen tension. This mechanism may be related to adverse effects observed under the supplementation of high doses of $\beta$-carotene. A study reported that supplements in doses of $20 \mathrm{mg}$ daily for 5-8 years had no protective effect on macrovascular outcomes or total mortality of diabetic male smokers [101]. Margalit et al. [24] reported that there was no significant difference between risks of lethal prostate cancer with the use of $\beta$-carotene during radiation therapy compared with that of placebo. Other trials about $\beta$-carotene supplementation will be required in order to clarify the protection role associated with $\beta$-carotene.

2.1.3. Lutein. Lutein is a yellow carotenoid synthetized in chloroplasts and chromoplasts and found in high quantities in leaves whose main function is to contribute to photosynthesis [102, 103]. It is one of the most widely found carotenoid xanthophyll pigments in fruits and vegetables normally consumed. Average lutein concentration in raw tomato was reported up to $32 \mu \mathrm{g} / 100 \mathrm{~g}$ FW [104], while GuilGuerrero and Rebolloso-Fuentes [105] reported a content up to $800 \mu \mathrm{g} / 100 \mathrm{~g} \mathrm{FW}$ in cherry variety. Increasing interest around this compound was due to its important role in preserving eye health in association with zeaxanthin [106]. The improvement of visual function and symptoms was 
also reported in atrophic age-related macular degeneration (ARMD), a condition including genetic, cardiovascular, nutritional, and environmental factors [22, 23]. Nevertheless, up to date, the relationship between the consumption of lutein and maintenance of normal vision has not been clearly demonstrated [107].

Epidemiological studies in vitro and in mouse model demonstrated that increased dietary intake of lutein is protective against the development of early atherosclerosis in human and animals through the reduction of inflammation and oxidative stress in the artery wall [46]. Kabagambe et al. [108] and Riccioni et al. [25] reported that there was an inverse correlation between the risk of developing a myocardial infarction, adipose tissue lutein content, and dietary lutein intake. Furthermore, carotid artery intimamedia thickness appears to be inversely correlated with serum lutein concentration [109]. Armoza et al. [47] studied the mechanisms involved in the action of tomato products in endothelial cells and demonstrated that inhibition of NF$\kappa \mathrm{B}$ signaling may be one of the main mechanisms employed by lutein and lycopene to reduce inflammatory leukocyte adhesion to endothelium.

Herrero-Barbudo et al. [26] reported that the regular consumption of lutein is associated with an increase of the capacity of DNA repair in lymphocytes and a major resistance of DNA to endogenous damage. Nevertheless, a real correlation between the consumption of lutein and protection of DNA, proteins, and lipids from oxidative damage has not been demonstrated yet [107].

2.2. Vitamins. Tomato protective action is commonly attributed to the tomato antioxidant lycopene. However, tomato products are also sources of other compounds such as vitamins $\mathrm{A}, \mathrm{B}$, and $\mathrm{E}$. Also these compounds have important effects on human health that will be described below.

2.2.1. Vitamin $E$. Vitamin $\mathrm{E}$ family includes eight molecules: $\alpha$-, $\beta$-, $\gamma^{-}$, and $\delta$-tocopherol; and $\alpha$-, $\beta$-, $\gamma^{-}$, and $\delta$-tocotrienol. This classification is based on the nature of the isoprenoid chain; tocopherols contain a phytyl chain while tocotrienols contain a geranylgeranyl chain. These molecules are potent liposoluble antioxidant. Tocopherols are the most abundant vitamins in tomato plant and contribute to maintain optimal plant photosynthesis rate under high levels of stress [60]. Frusciante et al. [3] reported a vitamin E level in tomatoes between 0.17 and $0.62 \mathrm{mg} / 100 \mathrm{gr}$ FW. Zanfini et al. [110] studied the antioxidant activity of lipophilic extracts obtained from different tomato varieties. They demonstrated a high synergistic effect of $\alpha$-tocopherol-lycopene mixtures, and also for lycopene- $\beta$-carotene, lycopene-lutein, and lutein$\beta$-carotene mixtures. This effect could be due to the fact that electrons can transfer from the carotenoid to the $\alpha$ tocopherolxyl radical to regenerate $\alpha$-tocopherol. An analogous mechanism has been suggested for the interactions between vitamin C, carotenoids, and $\alpha$-tocopherol [111]. A synergistic interaction between ascorbic acid and $\alpha$ tocopherol during the process of lipid peroxidation is well known [112]. This synergy was also observed during inhibition of the inflammation process [17].

Decreasing risk of advanced prostate cancer was associated with increasing dose of supplemental vitamin E uptake among men in the screening arm of the Prostate, Lung, Colorectal, and Ovarian Cancer Screening Trial [29].

In a study carried out on Finnish men and women, those who ingested higher intake of dietary vitamin $\mathrm{E}$ showed a decreased incidence of type 2 diabetes [30]. On the contrary, in a trial with a 10-year followup, with alternate-day doses of $600 \mathrm{IU}$ (international units) vitamin E, there was not a significant benefit for type 2 diabetes in initially healthy women [113]. Similar results were reported for the cardiovascular events and mortality in healthy women that ingested $600 \mathrm{IU}$ of natural-source vitamin E [114]. However, a study that evaluated the effect of adding tomato extract to the treatment regime of moderate hypertensives with uncontrolled blood pressure levels indicated a significant correlation between systolic blood pressure values and level of antioxidant activity [115].

2.2.2. Vitamin C. L-ascorbic acid and dehydroascorbic acid are the main dietary forms of vitamin $\mathrm{C}$, a labile molecule with reducing property. It is a water-soluble compound easily absorbed but it is not stored in the body. Abushita et al. [28] reported that salad tomatoes grown in field conditions contained between 15 and $21 \mathrm{mg} / 100 \mathrm{~g} \mathrm{FW}$, while a range of industrial grades of tomatoes had a mean value of $19 \mathrm{mg} / 100 \mathrm{~g} \mathrm{FW}$. Frusciante et al. [3] reported a vitamin C content between 8.0 and $16.3 \mathrm{mg} / 100 \mathrm{~g} \mathrm{FW}$.

Ascorbic acid (AsA) content in fresh tomatoes depends on genotype, climatic conditions, fruit development, maturation, senescence, and time of storage. AsA content in tomato fruit increases reaching a maximum and then began to decline with ripening [116]. Yahia et al. [117] reported a maximum level of $94.9 \mathrm{mg} / 100 \mathrm{~g}$ after 74 days from fruit set and slow reducing of its content with the color change. This decrease is concomitant with the increase in the activity of ascorbate oxidase, a $\mathrm{Cu}$-containing enzyme that catalyses the oxidation reaction of ascorbate to DHA with the reduction of molecular oxygen to water. Adults have a mean body pool of $1.2-2.0 \mathrm{~g}$ of ascorbic acid that may be maintained with $75 \mathrm{mg} /$ day of ascorbic acid [118]. Insufficient intakes of ascorbic acid lead to scurvy, a disease characterized by dry skin, open sores on the skin, weariness, impaired wound healing, and depression $[119,120]$.

Most of the known functions of ascorbic acid are correlated with its ability as electron donor and potent antioxidant in humans. In fact, vitamin $\mathrm{C}$ protects against oxidation of LDL by different types of oxidative stresses and inhibits LDL oxidation by vascular endothelial cells [120]. Yogeeta et al. [121] demonstrated that the combination of ferulic acid and ascorbic acid offered a protection to the myocardium. This was due to the attenuation of the alterations in the levels of lipids, lipid peroxidation, lipoprotein profile, and lipid metabolizing enzymes. Ascorbic acid with vitamin E prevents oxLDL-induced overexpression of vascular endothelial growth factor (VEGF) and its receptor is responsible for 
atherosclerotic plaque formation. In addition, vitamin $\mathrm{C}$ decreases plasma vascular cell adhesion molecule-1 responsible for monocyte adhesion and inflammation [31, 32].

Vitamin C in tomato is highly bioavailable, so a regular intake of small amounts of tomato products can increase cell protection from DNA damage induced by oxidant species. This effect may originate from the synergism of vitamin $\mathrm{C}$ with lycopene [122]. Some studies reported that ascorbic acid can prevent cancer by neutralizing free radicals before they can damage DNA and initiate tumor growth or may act as a prooxidant helping body to destroy tumors in their early stages [123]. Other researchers affirmed that there was no sufficient evidence that vitamin $\mathrm{C}$ and vitamin $\mathrm{E}$ can help prevent cancer [124].

Jacob et al. [33] discovered that the consumption of tomato juice $(500 \mathrm{~mL})$ for 2 weeks reduced total cholesterol and CRP (C-reactive protein) levels which is a marker of inflammation. The effect was stronger when vitamin $\mathrm{C}$ was added in a high dose. This study confirmed that a synergic effect between vitamin $\mathrm{C}$ and lycopene is required for the beneficial effects of tomato juice on oxidative stress and inflammation.

2.2.3. Folates. Folates represent all forms of vitamin B found in biological systems, while folic acid is the synthetic form found in dietary supplements and fortified foods [125]. Iniesta et al. [126] investigated the level of 5-methyltetrahydrofolate in commercial raw tomato cultivar harvested in Murcia (Spain). They found the maximum level in Ronaldo cultivar, equal to $31.5 \mu \mathrm{g} / 100 \mathrm{~g}$ FW.

Folate metabolism is involved in several physiological mechanisms in the field of andrology and gynecology [127]. In particular, folates have a role in various one-carbon transfer reactions, including purine and pyrimidine biosynthesis, amino acid metabolism, methylation of nucleic acids, proteins, and lipids [128]. For these reasons, folates are essential for fetal growth [129]. Folic acid supplementation $(200-400 \mu \mathrm{g} /$ day) is recommended for pregnant women to reduce pregnancy-induced folate deficiency, which can lead to megaloblastic anemia [34].

Homocysteine metabolism is regulated by the nutritional status of folate, vitamin B-12, and vitamin B-6 [130]. Some researchers consider hyperhomocysteinemia a marker for cardiovascular disease or a risk factor $[35,131,132]$.

2.3. Phenolics. Phenolic compounds are widespread phytochemicals composed of an aromatic ring and one or more hydroxyl substituents. They can be constituted by simple phenolic molecules or polymerised compounds [133, 134]. In tomato fruit, phenolics include flavonoids, phenolic acids (hydroxybenzoic and hydroxycinnamic acids), and tannins. Polyphenols are effective free radical scavengers mediated by para-hydroxyl group. Phenolics may modulate cellular signaling processes during inflammation or may serve as signaling agents themselves $[135,136]$. The level and the composition of phenolic compounds in tomato fruits depend greatly on genotype, environmental, and storage conditions [137]. In particular. Luthria et al. [138] demonstrated that the spectral quality of solar UV radiation significantly affects phenolic content.

Polyphenolic compounds are associated with therapeutic tools in inflammatory diseases including cardiovascular diseases, obesity and type II diabetes, neurodegenerative diseases, cancer, and aging.

These effects are due to the phenolic ability to interact with a wide spectrum of molecular targets central to the cellsignaling machinery. Main molecular mechanisms include (a) the inhibition of proinflammatory enzymes, such as cyclooxygenase (COX-2), lipoxygenase (LOX), and inducible nitric oxide synthase (iNOS); (b) the inhibition of phosphoinositide 3-kinase (PI 3-kinase), tyrosine kinases, and nuclear factor-kappa $\mathrm{B}(\mathrm{NF}-\kappa \mathrm{B})$; (c) the activation of peroxisome proliferators-activated receptor gamma (PPAR $\gamma)$; and (d) the activation of mitogen-activated protein kinase (MAPK), protein kinase $\mathrm{C}$ (PKC), and the modulation of several cell survival/cell-cycle genes [48, 49].

Studies reported that resveratrol increases the survival of mice fed with a high caloric diet producing changes including improvement in insulin sensitivity and decreased fat accumulation and body weight. These changes are associated with induction of mitochondrial-related transcription factors such as estrogen-related receptor $\alpha$ (ERR- $\alpha)$, nuclear respiratory factor 1 (NRF-1), and transcription mitochondrial factor A (TFAM). Potential beneficial effects of polyphenols have also been obtained for quercetin, able to reduce FFA levels, total cholesterol, and body weight in rats [139].

Finally, in 2007 Shen et al. [140] conducted a human clinical trial to examine plasma antioxidation and the levels of blood lipids, after ingestion of tomato products. The authors demonstrated that triglyceride levels and low-density lipoprotein cholesterol were decreased, while high-density lipoprotein cholesterol was increased.

2.3.1. Flavonoids. Flavonoids constitute the largest group of naturally occurring phenolics in tomatoes and contribute to the determination of aroma, fragrance, and colour [141, 142]. Main classes in tomatoes include flavonols (such as quercetin and kaempferol), flavanols (such as catechins), flavanones (such as naringerin), anthocyanidins, and stilbenes (such as resveratrol). They are usually located in the skin and only in small quantities in the other parts of the fruit. Tomatoes of the Spanish cherry variety Paloma reached levels of $203 \mu \mathrm{g}$ quercetin/g FW [143]. Detected levels of total flavonoids in tomatoes from commercial greenhouses in close proximity to Særheim Research Center were between 2.6 and $25.6 \mathrm{mg} / 100 \mathrm{FW}$ [144].

Some flavonoids such as rutin (a flavonol glycoside), quercetin, resveratrol, and catechin are active in rheumatoid arthritis. The mechanisms of action include inhibition of osteoclast/macrophage differentiation and function and estrogen modulation [50,53].

Rutin, quercetin, glycosides of quercetin, and resveratrol have been shown to exert intestinal anti-inflammatory activity $[37,38]$. In particular, rutin and quercetin have been proposed to act as quercetin prodrugs, preventing premature absorption of the aglycone in the small intestine and releasing 
it in the colon $[51,52]$. Quercetin exerts significant antiinflammatory effects on IL- $1 \beta$ activated human astrocytes, reducing cytokines and chemokines and oxidative stress [61].

Resveratrol acts on blood lipid levels and also at the atherosclerotic plaque and reduces cellular infiltration, fibrosis, and expression of inflammatory cytokines in a model of autoimmune myocarditis $[54,55]$.

Rossi et al. [145] conducted an epidemiological study in Italy that demonstrated a favorable role of dietary proanthocyanidins on gastric cancer risk, while Nishiumi et al. [39] reported that flavonoids modulate signal transduction pathways at each stage of carcinogenesis. After absorption, flavonoids are transported to target organs where they exert their anticarcinogenic activity.

Anthocyanins are one of the flavonoid phytopigments; they may act on adipocytes and modulate the expression levels of adipocytokines. In particular, C3G (cyanidin 3glucoside) was reported to upregulate the expression of adiponectin that can increase insulin sensitivity at the level of human adipocytes controlling obesity [56, 57]. In human endothelium, anthocyanins can inhibit TNF $\alpha$ induced inflammation through monocyte chemoattractant protein-1 [40]. In animal models, intake of anthocyanin fruit extracts improves cognitive and motor performance [146, 147].

2.3.2. Phenolic Acids. Phenolic acids are responsible for the astringent taste of vegetables [148]. They include hydroxybenzoic acids and hydroxycinnamic acids. Hydroxybenzoic acids are gallic, p-hydroxybenzoic, protocatechuic, syringic, and vanillic acids, while ferulic, caffeic, $p$-coumaric, and sinapic acids belong to hydroxycinnamic acids [134]. Chlorogenic acid is the most abundant in tomatoes. Martínez-Valverde et al. [149] analyzed tomatoes purchased in a local supermarket (Murcia, Spain). They reported amounts of chlorogenic acid between 14.31 (in Daniella variety) and $32.84 \mathrm{mg} / \mathrm{kg} \mathrm{FW}$ (in Senor variety), caffeic acid between 1.39 (in Senor variety) and 13.00 (in Ramillete variety), p-coumaric acid between values under limit of detection (in Liso and Remate varieties) and $5.77 \mathrm{mg} / \mathrm{kg}$ (in Daniella variety), and ferulic acid between 1.60 (in Riso variety) and 5.38 (in Durina variety) mg/kg FW.

Luthria et al. [138] identified amounts of $p$-coumaric acid between 3.5 and $5.5 \mathrm{mg} / 100 \mathrm{~g} \mathrm{FW}$, while the content of ferulic acid was between 0.9 and $1.5 \mathrm{mg} / 100 \mathrm{~g} \mathrm{FW}$.

Olthof et al. [150, 151] reported that half of the ingested chlorogenic acid was metabolized to hippuric acid. Therefore the colonic microflora transforms dietary phenols into metabolites that reach the circulation.

However, phenolic acids are studied mainly for their role as antioxidants $[62,63]$. Some studies reported a protective effect of caffeic acid and its related catechols against hydroxyl radical formation in vitro [64]. Lodovici et al. [41] investigated the effect of phenolic acids on oxidative DNA damage in vitro. They found that these compounds protected at low concentration in vitro against DNA oxidation induced by iron. Caffeic acid can block the biosynthesis of leukotrienes that are involved in immunoregulation. In addition, it was shown that caffeic acid possesses antitumor activity in humans [42]. Other studies reported a correlation between a series of phenolic acids with the inhibition of AP-1 transcriptional activity, implicated in the processes that control inflammation, cell differentiation, and proliferation [58].

Cinnamic acids exhibit strong antioxidant properties. 1,5-Dicaffeoylquinic is a hepatoprotector when challenged by carbon tetrachloride. This mechanism involves, among others, radical scavenging [65].

2.3.3. Tannins. Tannins include compounds of hydrolysable tannins that are polymers of ellagic acid, or gallic and ellagic acids, with glucose and condensed tannins (proanthocyanidins), which derive from the condensation of monomers of flavanol units $[152,153]$. They play an essential role in sensory properties of fruits and fruit products such as taste and color. Their antioxidant ability is exerted by scavenging free radicals, chelating trace metals, and binding proteins [66]. Some studies showed that tannins can enhance glucose uptake and inhibit adipogenesis, acting like potential drugs for the treatment of noninsulin dependent diabetes mellitus [43]. Koleckar et al. [44] reported that tannins, in addition to anti-inflammatory effects, have a role in the mechanisms of action of antibacterial, antiviral, anticarcinogenic, and cardiovascular system preventing.

\section{Effects of Processing on Tomato Chemical Composition}

Tomatoes are consumed fresh or are used to manufacture a wide range of processed products that can show a very different composition compared to fresh fruit. For example, significant losses of ascorbic acid can occur during postharvest storage period and during preparation and cooking of foods. This is due to oxidation and leaching into the water used for cooking $[75,154]$.

For the production of tomato paste from fresh tomatoes, both homogenization and heat treatment are used. Heat treatment and/or homogenization can disrupt the cellular matrix of tomatoes determining the bioavailability of different nutrients [155]. For example, retention of vitamin $\mathrm{C}$ improves with mild treatments and low temperatures [156]. Lycopene bioavailability was found increased after heat-processed tomatoes compared to fresh tomatoes [157, 158]. Other studies demonstrated that thermal processing of tomato pulp at $130^{\circ} \mathrm{C}$ improved the in vitro bioaccessibility of lycopene $[159,160]$. However, as bound antioxidants are released by processing, labile antioxidant compounds are destroyed simultaneously [28].

Veronica et al. [158] observed loss of vitamin $C$ in heatprocessed tomatoes at $88^{\circ} \mathrm{C}$ with an estimated $D 8_{88^{\circ} \mathrm{C}}$ value (the time taken for $90 \%$ reduction of the initial vitamin $\mathrm{C}$ content at $88^{\circ} \mathrm{C}$ ) of $276 \mathrm{~min}$. In addition, they found an antioxidant activity of raw tomatoes equal to $4.13 \pm 0.36 \mu \mathrm{mol}$ of vitamin $\mathrm{C}$ equiv/g of tomato. After heat treatment at $88^{\circ} \mathrm{C}$ for 2,15 , and $30 \mathrm{~min}$, the total antioxidant activity significantly increased to $5.29 \pm 0.26,5.53 \pm 0.24$, and $6.70 \pm$ 
$0.25 \mu \mathrm{mol}$ of vitamin $\mathrm{C}$ equiv/g of tomato, respectively $(P<$ $0.01)$. This effect could be explained by the increased amount of lycopene, the major phytochemical in tomatoes.

Gahler et al. [161] investigated how heat treatments affect the contents of vitamin $\mathrm{C}$ and polyphenols as well as the hydrophilic antioxidant capacity. Tomato juice was produced under industrial-like conditions; baked tomatoes as well as tomato sauce and tomato soup were prepared under household conditions. Vitamin C contents decreased during the thermal processing, while the total phenolics concentration and the water-soluble antioxidant capacity increased.

Seybold et al. [162] investigated the content of carotenoids and vitamin $\mathrm{E}$ in samples of tomato sauce, tomato soup, baked tomato slices, and tomato juice taken at different times of heating. $\beta$-Carotene amount decreased or was stable while $\alpha$-tocopherol content significantly rose during short-term heating.

Chang et al. [163] studied the effects of hot-air-drying (AD) treatment on tomato. They found that this process could enhance the nutritional value of tomatoes by increasing parts of the total flavonoids, total phenolics, and lycopene contents.

Patras et al. [164] reviewed the effect of thermal processing on content of anthocyanins. A combination of unit operations involving heat such as blanching, pasteurization, and duration affected the anthocyanin content of fruits and vegetables. Cyanidin-3-glucoside and pelargonidin-3glucoside in fruit puree were significantly affected by thermal process treatments of $70^{\circ} \mathrm{C}$ during holding times of $2 \mathrm{~min}$.

As a whole, these evidences could have a significant impact on consumer's food selection, increasing their awareness of the health benefits of processed tomatoes in the prevention of chronic diseases and inflammation.

\section{Biofortification}

The ability of various tomato phytonutrients to be positively correlated to prevent or ameliorate chronic disease is appealing. The studies carried out on the effects of phytochemicals on human health prompted researchers to find novel ways to get biofortified tomato genotypes with enhanced levels of phytonutrients such as anthocyanins, lycopene, ascorbic acid, and folate. In the last few years, crop biofortification gave an enormous contribution to understand the relationship between diet and health, reduce the risk of chronic disease, and better understand the regulatory systems in plant species. As described below, attempts to create novel tomato plant lines that carry genes for the accumulation of essential nutrients in tomato fruit can be achieved both through metabolic engineering and conventional breeding $[165,166]$ (Table 3).

4.1. Metabolic Engineering. Plant metabolic engineering adopted different biochemical approaches to improve the amount of various phytonutrients in tomato fruits. One strategy is based on modification of key-rate limiting steps in metabolic pathways. For example, the expression in tomato of two isoforms of the GDP-mannose- $3,5^{\prime}$-epimerase, a key enzyme of the ascorbic acid biosynthesis pathway, resulted in a modest increase of ascorbate (1.6-fold) in the fruits of transformed plant [167]. In another study, the cytosolic-targeted tomato Mdhar (monodehydroascorbate reductase) and Dhar (dehydroascorbate reductase) genes were overexpressed in tomato var. Micro-Tom. In the DHAR overexpressing lines, there was a 1.6-fold increase of AsA in fruits of plants grown in low light condition, while MDHAR transformants showed a reduced level of AsA by 0.7 -fold in mature green fruits [168]. Another approach in metabolic engineering is the expression of genes of a specific biosynthetic pathway belonging to other organisms. For example, attempts to increase AsA accumulation in tomato fruits were carried out by expression of the genes phytoene desaturase (crtI) of Erwinia uredovora and the yeast-derived GDP mannose pyrophosphorylase (GMPase) and arabinono-1,4-lactone oxidase (ALO) $[169,170]$. This strategy was also used to improve folate accumulation in fruit. The synthesis of tetrahydrofolate in mitochondria requires hydroxymethyl dihydropteridine (HMDHP), synthetized in the cytosol by GTP, and p-aminobenzoate (PABA), synthetized in chloroplasts from chorismate [171]. The first studies aimed to increase folate in tomato involved the overexpression of the bacterial GTP cyclohydrolase I (GCHI) to increase the supply of pteridines from cytosol. The transformed plants showed a low increase of folates (2- to 4-fold) in fruit probably because the supply of PABA became limiting $[165,172,173]$. The enhanced expression of a gene encoding for the aminodeoxychorismate synthase from Arabidopsis (AtADCS), aimed at increasing the supply of PABA, did not result in any change of folate levels in tomato fruit. On the contrary, the expression of GCHI and AtADCS resulted in 20-fold higher levels of folate compared to the control [171]. Using an alternative strategy, Apel and Bock [174] introduced the lycopene $\beta$-cyclase gene from the Eubacterium Erwinia herbicola and the higher plant Narcissus pseudonarcissus into the tomato plastid genome and obtained a 50\% increase in total carotenoid accumulation in genotypes expressing the plant enzyme. Other studies involve the accumulation of novel metabolites in tomato, such as resveratrol, using the expression of a gene encoding for a grape stilbene synthase [175]. Another approach to improve the levels of phytonutrient in plant organs consists in modulating regulatory genes whose products control flux through several biosynthetic pathways. For example, Davuluri et al. [176] enhanced the amount of anthocyans by suppressing an endogenous photomorphogenesis regulatory gene, DET1 (De-etiolated 1), using fruit-specific promoters combined with the RNA interference (RNAi) technology. The transformed plants showed an increase of flavonoid levels up to 3.5-fold. The last approach to increase levels of phytonutrients involves an enhancing expression of transcription factors that regulate specific biosynthetic pathways. This system does not work well in a complex branched pathway like those of folate biosynthesis [165] but seems to be very efficient to enhance the levels of secondary metabolites such as anthocyanins [177] and flavonols [184]. The anthocyanin pathway was modified in tomato using the transcription factors Delia (Del) and Roseal (Rosl) from snapdragon Antirrhinum majus. The fruit of transformed plants accumulated high level of 
TABLE 3: Results of biofortification through metabolic engineering and breeding in tomato.

\begin{tabular}{|c|c|c|c|c|}
\hline Approach & Technique & Gene & Pathway & References \\
\hline \multirow{9}{*}{$\begin{array}{l}\text { Metabolic } \\
\text { engineering }\end{array}$} & $\begin{array}{l}\text { Modification of a } \\
\text { key-rate limiting } \\
\text { step }\end{array}$ & $\begin{array}{l}\text { GDP-mannose- } 3,5^{\prime} \text {-epimerase } \\
\text { monodehydroascorbate reductase (Mdhar)- } \\
\text { dehydroascorbate reductase (Dhar) }\end{array}$ & Ascorbate & {$[167,168]$} \\
\hline & \multirow{6}{*}{$\begin{array}{l}\text { Heterologous gene } \\
\text { expression }\end{array}$} & Erwinia uredovora-phytoene desaturase (crtI) & $\beta$-Carotene & [169] \\
\hline & & $\begin{array}{l}\text { Arabidopsis-arabinono-1,4-lactone oxidase } \\
\text { (ALO) } \\
\text { Yeast-derived-GDP mannose pyrophosphorylase } \\
\text { (GMPase) }\end{array}$ & Ascorbic acid & {$[170]$} \\
\hline & & Bacterial GTP-cyclohydrolase I (GCHI) & Ascorbic acid & {$[170]$} \\
\hline & & $\begin{array}{l}\text { Arabidopsis-Aminodeoxychorismate synthase } \\
\text { (ADCS) }\end{array}$ & Folate & {$[165,171-173]$} \\
\hline & & Erwinia herbicola lycopene b-cyclase & Carotenoid & {$[174]$} \\
\hline & & Grape stylbene synthase & Resveratrol & {$[175]$} \\
\hline & $\begin{array}{l}\text { Silencing pathway } \\
\text { bottle neck }\end{array}$ & De-etiolated1 (DET-)1 & Anthocyans & {$[176]$} \\
\hline & $\begin{array}{l}\text { Increase levels of } \\
\text { transcription } \\
\text { factors }\end{array}$ & $\begin{array}{l}\text { Delia }(\text { Del }) \text { and Roseal (Ros1) } \\
\text { AtMYB12 }\end{array}$ & $\begin{array}{l}\text { Anthocyans } \\
\text { Polyphenols }\end{array}$ & $\begin{array}{l}{[177]} \\
{[177]}\end{array}$ \\
\hline \multirow{5}{*}{$\begin{array}{l}\text { Conventional } \\
\text { breeding }\end{array}$} & $\begin{array}{l}\text { Association } \\
\text { mapping QTL }\end{array}$ & 29 SSR and 15 morpho-physiological traits & Anthocyans & {$[178]$} \\
\hline & \multirow{4}{*}{$\begin{array}{l}\text { QTL linkage } \\
\text { mapping }\end{array}$} & Lyc 7.1 and $l y c 12.1$ & Lycopene & {$[179]$} \\
\hline & & \multirow{3}{*}{ Variation during the plant development } & Various components & {$[180]$} \\
\hline & & & $\begin{array}{l}\text { Ascorbic acid, phenols, and } \\
\text { soluble solid }\end{array}$ & {$[181,182]$} \\
\hline & & & $\begin{array}{l}\text { Total phenols and }{ }^{\circ} \mathrm{Bx} \\
\text { content }\end{array}$ & {$[183]$} \\
\hline
\end{tabular}

anthocyanins with concentrations similar to those found in blackberries and blueberries [177]. Another transcription factor (AtMYB12), which regulates the caffeoylquinic acid and flavonol synthesis, proved to be a good candidate for the production of tomato fruits with high levels of polyphenolic antioxidants compounds [184]. Drawbacks of this strategy are that not all the transcription factors regulating pathway have been identified and that transcriptional regulators could have pleiotropic effects when their expression is enhanced $[165,177,185]$.

4.2. Plant Breeding. One way to produce biofortified plants is to take advantage of the natural variation of plant genomes. For example, recently a new genetic combination was obtained through conventional breeding, which produced a phenotype with deep purple fruit pigmentation, due to an accumulation of anthocyanins on the peels. Such a genotype was named Sun Black [178]. Tomato fruit quality usually exhibits quantitative variation controlled by several genes and influenced by environment. For these reasons one main focus of genetic studies has been the identification of genes and quantitative trait loci (QTL) that control the accumulation in tomato fruit of phytonutrients, such as lycopene [165, 178, 179]. As for other crops, the improvement of tomato depends on the availability of genetic variability. However, the germplasm of cultivated tomato shows a reduced genetic variability, both for its natural reproduction systems (autogamy) and as a consequence of domestication and breeding, the latter often based on intercrossing advanced lines. In contrast, wild species (such as S. pimpinellifolium, S. neorickii, S. habrochaites, S. chmielewskii, and S. pennellii) and heirlooms tomatoes have a rich genetic variability; therefore, one goal of plant breeding has become to screen wild genetic resources for valuable traits that could be introduced into modern varieties to improve specific traits [180, 186, 187]. In this regard, it is noteworthy that the work of Schauer et al. [187], in order to identify components of fruit metabolic composition, has phenotyped tomato introgression lines (IL) in which marker-defined genomic regions of the wild species Solanum pennellii were replaced with homologous intervals of the cultivated variety M82. In our laboratory, two introgression lines of Solanum pennellii were identified harboring QTLs that increase the content of ascorbic acid, phenols, and soluble solids [181, 182]. In a subsequent work, the selected QTLs were pyramided into cultivated varieties to increase antioxidant content in tomato fruits [183]. Although the conventional breeding is a good strategy to improve the quality of tomato fruit, this technique has some limitations due to sexual incompatibility and requires long breeding programs, whereas genetic engineering has no such limitations and novel genes can be introduced directly into local cultivars. Today, several genomic resources are available for tomato, such as high-density genetic maps, genomic and cDNA libraries, chip Illumina, germplasm collections, and 
TABLE 4: Advantages and disadvantages of metabolic engineering and plant breeding.

\begin{tabular}{|c|c|}
\hline Metabolic engineering & Plant breeding \\
\hline \multicolumn{2}{|c|}{ Advantages } \\
\hline $\begin{array}{l}\text { (i) Fast } \\
\text { (ii) Easy to apply to the elite } \\
\text { cultivar } \\
\text { (iii) Genes from other organism } \\
\text { can be inserted } \\
\text { (iv) Genes are inserted directly } \\
\text { into the plant genome and are } \\
\text { transmitted to offspring } \\
\text { (v) Possible selection of the } \\
\text { expression organs }\end{array}$ & $\begin{array}{l}\text { (i) It uses the natural genome } \\
\text { variation of crop } \\
\text { (ii) Few legal regulations to } \\
\text { follow }\end{array}$ \\
\hline
\end{tabular}

Disadvantages

(i) Restricted to the crop gene pool

(i) Many legal regulations regarding the landscape

(ii) Political and socioeconomic disputes about the "transgenics"

(ii) Restricted to the only sexually compatible plants (iii) It needs work for a long time and with a high number of generations to have plants with the genes of interest populations of introgression lines [188]. In addition, the sequence of the tomato genome has recently been completed (http://solgenomics.net/organism/solanum_lycopersicum/ge nome) by an international consortium [189]. Using the existing genetic resources and genomic tools, it is now possible to integrate and apply the information of the genome sequence to discover new genes and allelic variants for genetic traits important for consumers, such as fruit quality. One of the most likely outcomes of the availability of the tomato genome sequence will be the development of high-throughput molecular markers to be used for genetic analysis and breeding programs and the discovery of novel genes. Moreover, by combining the sequence of tomato genome with the possibility of massive resequencing, it is now possible to investigate the genetic variability in large populations of individuals with the aim of identifying polymorphisms (SNPs/indels) in a panel of candidate genes. Finally, the use of approaches, such as RNA-seq, also called "Whole Transcriptome Shotgun Sequencing" ("WTSS"), provides a new gateway to identify the level of gene expression, new transcripts, splice variants, and expressed SNPs [190]. In Table 4, the main advantages and disadvantages of metabolic engineering and plant breeding are summarized.

\section{Conclusion}

There are many evidences supporting the anti-inflammatory and anticancer action of tomato fruit bioactive compounds. Molecular mechanisms controlling these effects have been extensively studied and described.

The present review reports a brief description, even though not exhaustive, of bioactive compounds available in tomato fruit and of their beneficial properties on human health.

The content of these compounds might be increased to obtain biofortified food taking into account, among other things, the great influence of processing transformation that is required for some derived tomato foods. Various strategies might be used to increase these compounds in tomato fruit. Therefore, the final destination of biofortified tomatoes needs to be considered when selecting new genotypes for fresh market or processing.

It is necessary to dissect tomatoes complex genetic control to identify key genes of biochemical pathways underlying their biosynthesis.

The best strategy to transfer them into improved genotypes might be chosen between metabolic engineering via genetic transformation and precision breeding by the aid of molecular markers.

In both cases, the richness of genetic and genomic resources today available for tomato might highly enhance the success of tomato breeding aimed to obtain new biofortified genotypes.

\section{Conflict of Interests}

The authors declare that there is no conflict of interests regarding the publication of this paper.

\section{Acknowledgment}

The authors would like to thank GenoPOM-pro Project (PON02_00395_3082360) for the financial support to their activities and for its contribution to increase their knowledge.

\section{References}

[1] U. S. Department of Agriculture, "Economic Research Service," Tomatoes, 2008, http://www.ers.usda.gov/.

[2] K. Canene-Adams, J. K. Campbell, S. Zaripheh, E. H. Jeffery, and J. W. Erdman Jr., "The tomato as a functional food," Journal of Nutrition, vol. 135, no. 5, pp. 1226-1230, 2005.

[3] L. Frusciante, P. Carli, M. R. Ercolano et al., "Antioxidant nutritional quality of tomato," Molecular Nutrition and Food Research, vol. 51, no. 5, pp. 609-617, 2007.

[4] Z. Kotíková, J. Lachman, A. Hejtmánková, and K. Hejtmánková, "Determination of antioxidant activity and antioxidant content in tomato varieties and evaluation of mutual interactions between antioxidants," Food Science and Technology, vol. 44, pp. 1703-1710, 2011.

[5] M. J. Periago, J. García-Alonso, K. Jacob et al., "Bioactive compounds, folates and antioxidant properties of tomatoes (Lycopersicum esculentum) during vine ripening," International Journal of Food Sciences and Nutrition, vol. 60, no. 8, pp. 694-708, 2009.

[6] V. García-Valeverde, I. Navarro-Gonzáles, J. García-Alonso, and M. J. Periago, "Antioxidant bioactive compounds in selected industrial processing and fresh consumption tomato cultivars," Food and Bioprocess Technology, vol. 6, no. 2, pp. 391-402, 2013.

[7] M. M. Rigano, G. de Guzman, A. M. Walmsley, L. Frusciante, and A. Barone, "Production of pharmaceutical proteins in 
Solanaceae food crops," International Journal of Molecular Sciences, vol. 14, pp. 2753-2773, 2013.

[8] C. Rosati, R. Aquilani, S. Dharmapuri et al., "Metabolic engineering of beta-carotene and lycopene content in tomato fruit," Plant Journal, vol. 24, no. 3, pp. 413-419, 2000.

[9] J. A. Labate, S. Grandillo, T. Fulton et al., “Tomato," in Genome Mapping and Molecular Breeding in Plants: Vol. 5 Vegetables, C. Kole, Ed., pp. 1-125, Springer, New York, NY, USA, 2007.

[10] F. Visioli, P. Riso, S. Grande, C. Galli, and M. Porrini, "Protective activity of tomato products on in vivo markers of lipid oxidation," European Journal of Nutrition, vol. 42, no. 4, pp. 201-206, 2003.

[11] M.-L. Silaste, G. Alfthan, A. Aro, Y. A. Kesäniemi, and S. Hörkkö, "Tomato juice decreases LDL cholesterol levels and increases LDL resistance to oxidation," British Journal of Nutrition, vol. 98, no. 6, pp. 1251-1258, 2007.

[12] B. Burton-Freeman, J. Talbot, E. Park, S. Krishnankutty, and I. Edirisinghe, "Protective activity of processed tomato products on postprandial oxidation and inflammation: a clinical trial in healthy weight men and women," Molecular Nutrition and Food Research, vol. 56, no. 4, pp. 622-631, 2012.

[13] M. Porrini, P. Riso, A. Brusamolino, C. Berti, S. Guarnieri, and F. Visioli, "Daily intake of a formulated tomato drink affects carotenoid plasma and lymphocyte concentrations and improves cellular antioxidant protection," British Journal of Nutrition, vol. 93, no. 1, pp. 93-99, 2005.

[14] E. Gouranton, C. Thabuis, C. Riollet et al., "Lycopene inhibits proinflammatory cytokine and chemokine expression in adipose tissue," Journal of Nutritional Biochemistry, vol. 22, no. 7, pp. 642-648, 2011.

[15] R. E. Simone, M. Russo, A. Catalano et al., "Lycopene inhibits NF-KB-Mediated IL-8 expression and changes redox and PPAR $\gamma$ signalling in cigarette smoke-stimulated macrophages," PLoS ONE, vol. 6, no. 5, Article ID e19652, pp. 1-11, 2011.

[16] N. Markovits, A. B. Amotz, and Y. Levy, "The effect of tomatoderived lycopene on low carotenoids and enhanced systemic inflammation and oxidation in severe obesity," Israel Medical Association Journal, vol. 11, no. 10, pp. 598-601, 2009.

[17] T. H. Rissanen, S. Voutilainen, K. Nyyssönen, R. Salonen, G. A. Kaplan, and J. T. Salonen, "Serum lycopene concentrations and carotid atherosclerosis: the Kuopio Ischaemic Heart Disease Risk Factor Study," American Journal of Clinical Nutrition, vol. 77, no. 1, pp. 133-138, 2003.

[18] M. Gonzáles-Vallinas, M. Gonzáles-Catejón, A. RodríguezCasado, and A. Ramírez de Molina, "Dietary phytochemicals in cancer prevention and therapy: a complementary approach with promising perspectives," Nutrition Reviews, vol. 71, no. 9, pp. 585-599, 2013.

[19] M. S. Ansari and N. P. Gupta, "Lycopene: a novel drug therapy in hormone refractory metastatic prostate cancer," Urologic Oncology, vol. 22, no. 5, pp. 415-420, 2004.

[20] W. Stahl and H. Sies, "Antioxidant activity of carotenoids," Molecular Aspects of Medicine, vol. 24, no. 6, pp. 345-351, 2003.

[21] J. Karppi, S. Kurl, T. H. Mäkikallio, K. Ronkainen, and J. A. Laukkanen, "Serum $\beta$-carotene concentrations and the risk of congestive heart failure in men: a population-based study," International Journal of Cardiology, vol. 168, no. 3, pp. 1841-1846, 2013.

[22] S. Richer, W. Stiles, L. Statkute et al., "Double-masked, placebocontrolled, randomized trial of lutein and antioxidant supplementation in the intervention of atrophic age-related macular degeneration: the Veterans LAST study (Lutein Antioxidant Supplementation Trial)," Optometry, vol. 75, no. 4, pp. 216-230, 2004.

[23] J. P. SanGiovanni, E. Y. Chew, T. E. Clemons et al., "The relationship of dietary carotenoid and vitamin A, E, and C intake with age-related macular degeneration in a case-control study: AREDS report No. 22," Archives of Ophthalmology, vol. 125, no. 9, pp. 1225-1232, 2007.

[24] D. N. Margalit, J. L. Kasperzyk, N. E. Martin et al., "Betacarotene antioxidant use during radiation therapy and prostate cancer outcome in the physicians' health study," International Journal of Radiation Oncology Biology Physics, vol. 83, no. 1, pp. 28-32, 2012.

[25] G. Riccioni, L. Speranza, M. Pesce, S. Cusenza, N. D’Orazio, and M. J. Glade, "Novel phytonutrient contributors to antioxidant protection against cardiovascular disease," Nutrition, vol. 28, no. 6, pp. 605-610, 2012.

[26] C. Herrero-Barbudo, B. Soldevilla, B. Pérez-Sacristán et al., "Modulation of DNA-induced damage and repair capacity in humans after dietary Intervention withlutein-enriched fermented milk," PLOS ONE, vol. 8, no. 9, pp. 1-6, 2013.

[27] M. Hazewindus, G. R. M. M. Haenen, A. R. Weseler, and A. Bast, "The anti-inflammatory effect of lycopene complements the antioxidant action of ascorbic acid and $\alpha$-tocopherol," Food Chemistry, vol. 132, no. 2, pp. 954-958, 2012.

[28] A. A. Abushita, H. G. Daood, and P. A. Biacs, "Change in carotenoids and antioxidant vitamins in tomato as a function of varietal and technological factors," Journal of Agricultural and Food Chemistry, vol. 48, no. 6, pp. 2075-2081, 2000.

[29] V. A. Kirsh, R. B. Hayes, S. T. Mayne et al., "Supplemental and dietary vitamin $\mathrm{E}, \beta$-carotene, and vitamin $\mathrm{C}$ intakes and prostate cancer risk," Journal of the National Cancer Institute, vol. 98, no. 4, pp. 245-254, 2006.

[30] J. Montonen, P. Knekt, R. Järvinen, and A. Reunanen, “Dietary Antioxidant Intake and Risk of Type 2 Diabetes," Diabetes Care, vol. 27, no. 2, pp. 362-366, 2004.

[31] J. A. Rodríguez, B. Nespereira, M. Pérez-Ilzarbe, E. Eguinoa, and J. A. Páramo, "Vitamins $\mathrm{C}$ and E prevent endothelial VEGF and VEGFR-2 overexpression induced by porcine hypercholesterolemic LDL," Cardiovascular Research, vol. 65, no. 3, pp. 665673, 2005.

[32] Y. Li and H. E. Schellhorn, "New developments and novel therapeutic perspectives for vitamin C," Journal of Nutrition, vol. 137, no. 10, pp. 2171-2184, 2007.

[33] K. Jacob, M. J. Periago, V. Böhm, and G. R. Berruezo, "Influence of lycopene and vitamin $\mathrm{C}$ from tomato juice on biomarkers of oxidative stress and inflammation," British Journal of Nutrition, vol. 99, no. 1, pp. 137-146, 2008.

[34] Food and Nutrition Board and National Research Council, Maternal Nutrition and the Course of Pregnancy, National Academy of Sciences, Washington, DC, USA, 1970.

[35] A. Solini, E. Santini, and E. Ferrannini, "Effect of short-term folic acid supplementation on insulin sensitivity and inflammatory markers in overweight subjects," International Journal of Obesity, vol. 30, no. 8, pp. 1197-1202, 2006.

[36] P. de Wals, F. Tairou, M. I. van Allen et al., "Reduction in neuraltube defects after folic acid fortification in Canada," The New England Journal of Medicine, vol. 357, no. 2, pp. 135-142, 2007.

[37] A. R. Martín, I. Villegas, M. Sánchez-Hidalgo, and C. A. de la Lastra, "The effects of resveratrol, a phytoalexin derived from 
red wines, on chronic inflammation induced in an experimentally induced colitis model," British Journal of Pharmacology, vol. 147, no. 8, pp. 873-885, 2006.

[38] R. Gonzáles, I. Ballester, R. López-Posadas et al., "Effects of flavonoids and other polyphenols on inflammation," Critical Reviews in Food Science and Nutrition, vol. 51, no. 4, pp. 331362, 2011.

[39] S. Nishiumi, S. Miyamoto, K. Kawabata et al., "Dietary flavonoids as cancer-preventive and therapeutic biofactors," Frontiers in bioscience (Scholar edition), vol. 3, pp. 1332-1362, 2011.

[40] M. Garcia-Alonso, A.-M. Minihane, G. Rimbach, J. C. RivasGonzalo, and S. de Pascual-Teresa, "Red wine anthocyanins are rapidly absorbed in humans and affect monocyte chemoattractant protein 1 levels and antioxidant capacity of plasma," Journal of Nutritional Biochemistry, vol. 20, no. 7, pp. 521-529, 2009.

[41] M. Lodovici, F. Guglielmi, M. Meoni, and P. Dolara, "Effect of natural phenolic acids on DNA oxidation in vitro," Food and Chemical Toxicology, vol. 39, no. 12, pp. 1205-1210, 2001.

[42] N. Rajendra Prasad, A. Karthikeyan, S. Karthikeyan, and B. Venkata Reddy, "Inhibitory effect of caffeic acid on cancer cell proliferation by oxidative mechanism in human HT-1080 fibrosarcoma cell line," Molecular and Cellular Biochemistry, vol. 349, no. 1-2, pp. 11-19, 2011.

[43] R. M. Seabra, P. B. Andrade, P. Valentão, E. Fernandes, F. Carvalho, and M. L. Bastos, "Molecules 2009,14," in Biomaterials From Aquatic and Terrestrial Organisms, M. Fingerman and R. Nagabhushanam, Eds., pp. 15-174, Science Publishers, Enfield, NH, USA, 2006.

[44] V. Koleckar, K. Kubikova, Z. Rehakova et al., "Condensed and hydrolysable tannins as antioxidants influencing the health," Mini-Reviews in Medicinal Chemistry, vol. 8, no. 5, pp. 436-447, 2008.

[45] M. M. Ciccone, F. Cortese, M. Gesualdo et al., "Dietary intake of carotenoids and their antioxidant and anti-inflammatory effects in cardiovascular care," Mediators of Inflammation, vol. 2013, Article ID 782137, 11 pages, 2013.

[46] J. H. Dwyer, M. Navab, K. M. Dwyer et al., "Oxygenated carotenoid lutein and progression of early atherosclerosis: the Los Angeles atherosclerosis study," Circulation, vol. 103, no. 24, pp. 2922-2927, 2001.

[47] A. Armoza, Y. Haim, A. Bashiri, T. Wolak, and E. Paran, "Tomato extract and the carotenoids lycopene and lutein improve endothelial function and attenuate inflammatory NF$\kappa \mathrm{B}$ signaling in endothelial cells," Journal of Hypertension, vol. 31, no. 3, pp. 521-529, 2013.

[48] W.-X. Tian, "Inhibition of fatty acid synthase by polyphenols," Current Medicinal Chemistry, vol. 13, no. 8, pp. 967-977, 2006.

[49] C. Santangelo, R. Varì, B. Scazzocchio, R. di Benedetto, C. Filesi, and R. Masella, "Polyphenols, intracellular signalling and inflammation," Annali dell'Istituto Superiore di Sanita, vol. 43, no. 4, pp. 394-405, 2007.

[50] T. Kauss, D. Moynet, J. Rambert et al., "Rutoside decreases human macrophage-derived inflammatory mediators and improves clinical signs in adjuvant-induced arthritis," Arthritis Research and Therapy, vol. 10, no. 1, article R19, 2008.

[51] K. H. Kwon, A. Murakami, T. Tanaka, and H. Ohigashi, "Dietary rutin, but not its aglycone quercetin, ameliorates dextran sulfate sodium-induced experimental colitis in mice: attenuation of pro-inflammatory gene expression," Biochemical Pharmacology, vol. 69, no. 3, pp. 395-406, 2005.
[52] M. Comalada, D. Camuesco, S. Sierra et al., "In vivo quercitrin anti-inflammatory effect involves release of quercetin, which inhibits inflammation through down-regulation of the NF- $\kappa \mathrm{B}$ pathway," European Journal of Immunology, vol. 35, no. 2, pp. 584-592, 2005.

[53] Q. Wang, M. Xia, C. Liu et al., "Cyanidin-3-O- $\beta$-glucoside inhibits iNOS and COX-2 expression by inducing liver $\mathrm{X}$ receptor alpha activation in THP-1 macrophages," Life Sciences, vol. 83, no. 5-6, pp. 176-184, 2008.

[54] S. Zhou, Y. Hu, B. Zhang et al., "Dose-dependent absorption, metabolism, and excretion of genistein in rats," Journal of Agricultural and Food Chemistry, vol. 56, no. 18, pp. 8354-8359, 2008.

[55] Y. Kawai, T. Nishikawa, Y. Shiba et al., "Macrophage as a target of quercetin glucuronides in human atherosclerotic arteries: implication in the anti-atherosclerotic mechanism of dietary flavonoids," Journal of Biological Chemistry, vol. 283, no. 14, pp. 9424-9434, 2008.

[56] T. Tsuda, F. Horio, K. Uchida, H. Aoki, and T. Osawa, "Dietary cyanidin 3-O- $\beta$-D-glucoside-rich purple corn color prevents obesity and ameliorates hyperglycemia in mice," Journal of Nutrition, vol. 133, no. 7, pp. 2125-2130, 2003.

[57] T. Tsuda, "Dietary anthocyanin-rich plants: biochemical basis and recent progress in health benefits studies," Molecular Nutrition and Food Research, vol. 56, no. 1, pp. 159-170, 2012.

[58] P. J. King, G. Ma, W. Miao et al., "Structure-activity relationships: analogues of the dicaffeoylquinic and dicaffeoyltartaric acids as potent inhibitors of human immunodeficiency virus type 1 integrase and replication," Journal of Medicinal Chemistry, vol. 42, no. 3, pp. 497-509, 1999.

[59] P. di Tomo, R. Canali, D. Ciavardelli et al., “ $\beta$-Carotene and lycopene affect endothelial response to TNF- $\alpha$ reducing nitrooxidative stress and interaction with monocytes," Molecular Nutrition and Food Research, vol. 56, no. 2, pp. 217-227, 2012.

[60] S. Porfirova, E. Bergmüller, S. Tropf, R. Lemke, and P. Dörmann, "Isolation of an Arabidopsis mutant lacking vitamin E and identification of a cyclase essential for all tocopherol biosynthesis," Proceedings of the National Academy of Sciences of the United States of America, vol. 99, no. 19, pp. 12495-12500, 2002.

[61] V. Sharma, M. Mishra, S. Ghosh et al., "Modulation of interleukin- $1 \beta$ mediated inflammatory response in human astrocytes by flavonoids: implications in neuroprotection," Brain Research Bulletin, vol. 73, no. 1-3, pp. 55-63, 2007.

[62] C. A. Rice-Evans, N. J. Miller, and G. Paganga, "Antioxidant properties of phenolic compounds," Trends in Plant Science, vol. 2, no. 4, pp. 152-159, 1997.

[63] R. J. Robbins, "Phenolic acids in foods: an overview of analytical methodology," Journal of Agricultural and Food Chemistry, vol. 51, no. 10, pp. 2866-2887, 2003.

[64] F. A. M. Silva, F. Borges, C. Guimarães, J. L. F. C. Lima, C. Matos, and S. Reis, "Phenolic acids and derivatives: studies on the relationship among structure, radical scavenging activity, and physicochemical parameters," Journal of Agricultural and Food Chemistry, vol. 48, no. 6, pp. 2122-2126, 2000.

[65] J. Bruneton, Pharmacognosie: Phytochimie, Plantes Médicinales, Éditions Tec \& Doc, Paris, France, 1999.

[66] A. Szajdek and E. J. Borowska, "Bioactive compounds and health-promoting properties of berry fruits: a review," Plant Foods for Human Nutrition, vol. 63, no. 4, pp. 147-156, 2008.

[67] A. V. Rao and L. G. Rao, "Carotenoids and human health," Pharmacological Research, vol. 55, no. 3, pp. 207-216, 2007. 
[68] H. Gerster, "The potential role of lycopene for human health," Journal of the American College of Nutrition, vol. 16, no. 2, pp. 109-126, 1997.

[69] S. A. Aherne, M. A. Jiwan, T. Daly, and N. M. O’Brien, "Geographical location has greater impact on carotenoid content and bioaccessibility from tomatoes than variety," Plant Foods for Human Nutrition, vol. 64, no. 4, pp. 250-256, 2009.

[70] G. Maiani, M. J. Caston, and G. Catasta, "Carotenoids: actual knowledge on food sources, intakes, stability and bioavailability and their protective role in humans," Molecular Nutrition \& Food Research, vol. 53, supplement 2, pp. S194-S218, 2009.

[71] D. Heber and Q.-Y. Lu, "Overview of mechanisms of action of lycopene," Experimental Biology and Medicine, vol. 227, no. 10, pp. 920-923, 2002.

[72] Y. Sharoni, M. Danilenko, N. Dubi, A. Ben-Dor, and J. Levy, "Carotenoids and transcription," Archives of Biochemistry and Biophysics, vol. 430, no. 1, pp. 89-96, 2004.

[73] K. W. Kong and A. Ismail, "Lycopene content and lipophilic antioxidant capacity of by-products from Psidium guajava fruits produced during puree production industry," Food and Bioproducts Processing, vol. 89, no. 1, pp. 53-61, 2011.

[74] G. L. Renju, G. M. Kurup, and C. H. Saritha Kumari, "Effect of lycopene from Chlorella marina on high cholesterol-induced oxidative damage and inflammation in rats," Inflammopharmacology, 2013.

[75] E. Sahlin, G. P. Savage, and C. E. Lister, "Investigation of the antioxidant properties of tomatoes after processing," Journal of Food Composition and Analysis, vol. 17, no. 5, pp. 635-647, 2004.

[76] G. Ronen, M. Cohen, D. Zamir, and J. Hirschberg, "Regulation of carotenoid biosynthesis during tomato fruit development: expression of the gene for lycopene epsilon-cyclase is downregulated during ripening and is elevated in the mutant Delta," Plant Journal, vol. 17, no. 4, pp. 341-351, 1999.

[77] E. Hernandez-Marin, A. Galano, and A. Martínez, "Cis carotenoids: colorful molecules and free radical quenchers," The Journal of Physical Chemistry B, vol. 117, no. 15, pp. 4050-4061, 2013.

[78] T. W.-M. Boileau, A. C. Boileau, and J. W. Erdman Jr., "Bioavailability of all-trans and cis-isomers of lycopene," Experimental Biology and Medicine, vol. 227, no. 10, pp. 914-919, 2002.

[79] M. Friedman, "Anticarcinogenic, cardioprotective, and other health benefts of tomato compounds lycopene, $\alpha$-tomatine, and tomatidine in pure form and in fresh and processed tomatoes," Journal of Agricultural and Food Chemistry, vol. 61, no. 40, pp. 9534-9550, 2013.

[80] B. Halliwell and C. E. Cross, "Oxygen-derived species: their relation to human disease and environmental stress," Environmental Health Perspectives, vol. 102, supplement 10, pp. 5-12, 1994.

[81] L. A. Pham-Huy, H. He, and C. Pham-Huy, "Free radicals, antioxidants in disease and health," International Journal of Biomedical Science, vol. 4, no. 2, pp. 89-96, 2008.

[82] B. Halliwell and S. Chirico, "Lipid peroxidation: its mechanism, measurement, and significance," American Journal of Clinical Nutrition, vol. 57, no. 5, pp. 715S-724S, 1993.

[83] M. S. Hayden, A. P. West, and S. Ghosh, "NF- $\kappa$ B and the immune response," Oncogene, vol. 25, no. 51, pp. 6758-6780, 2006.

[84] D. Feng, W.-H. Ling, and R.-D. Duan, "Lycopene suppresses LPS-induced NO and IL- 6 production by inhibiting the activation of ERK, p38MAPK, and NF- $\kappa$ B in macrophages," Inflammation Research, vol. 59, no. 2, pp. 115-121, 2010.
[85] H. Amir, M. Karas, J. Giat et al., "Lycopene and 1,25dihydroxyvitamin D3 cooperate in the inhibition of cell cycle progression and induction of differentiation in HL-60 leukemic cells," Nutrition and Cancer, vol. 33, no. 1, pp. 105-112, 1999.

[86] D. Ilic, K. Forbes, and C. Hassed, "Lycopene for the prevention of prostate cancer," Cochrane Database of Systematic Reviews, no. 11, Article ID CD008007, 2009.

[87] D. Ilic, M. M. Neuberger, M. Djulbegovic, and P. Dahm, "Screening for prostate cancer," Cochrane Database of Systematic Reviews, vol. 1, pp. 1-63, 2013.

[88] M. B. Sporn and K. T. Liby, "Is lycopene an effective agent for preventing prostate cancer," Cancer Prevention Research, vol. 6, no. 5, pp. 384-386, 2013.

[89] E. Heath, S. Seren, K. Sahin, and O. Kucuk, "The role of tomato lycopene in the treatment of prostate cancer," in Tomatoes, Lycopene and Human Health, A. V. Rao, Ed., pp. 127-140, Caledonian Science Press, 2006.

[90] Q.-Y. Lu, J.-C. Hung, D. Heber et al., "Inverse associations between plasma lycopene and other carotenoids and prostate cancer," Cancer Epidemiology Biomarkers and Prevention, vol. 10, no. 7, pp. 749-756, 2001.

[91] C. Martin, Y. Zhang, C. Tonelli, and K. Petroni, "Plants, diet, and health," Annual Review of Plant Biology, vol. 64, pp. 19-46, 2013.

[92] H. S. Park, J. Y. Park, and R. Yu, "Relationship of obesity and visceral adiposity with serum concentrations of CRP, TNF- $\alpha$ and IL-6," Diabetes Research and Clinical Practice, vol. 69, no. 1, pp. 29-35, 2005.

[93] J. M. Argilés, J. López-Soriano, V. Almendro, S. Busquets, and F. J. López-Soriano, "Cross-talk between skeletal muscle and adipose tissue: a link with obesity?" Medicinal Research Reviews, vol. 25, no. 1, pp. 49-65, 2005.

[94] L. di Renzo, A. Bertoli, M. Bigioni et al., "Body composition and -174G/C interleukin-6 promoter gene polymorphism: association with progression of insulin resistance in normal weight obese syndrome," Current Pharmaceutical Design, vol. 14, no. 26, pp. 2699-2706, 2008.

[95] P. Riso, F. Visioli, S. Grande et al., "Effect of a tomato-based drink on markers of inflammation, immunomodulation, and oxidative stress," Journal of Agricultural and Food Chemistry, vol. 54, no. 7, pp. 2563-2566, 2006.

[96] A. Raffo, C. Leonardi, V. Fogliano et al., "Nutritional value of cherry tomatoes (Lycopersicon esculentum cv. Naomi F1) harvested at different ripening stages," Journal of Agricultural and Food Chemistry, vol. 50, no. 22, pp. 6550-6556, 2002.

[97] J. Scalzo, A. Politi, N. Pellegrini, B. Mezzetti, and M. Battino, "Plant genotype affects total antioxidant capacity and phenolic contents in fruit," Nutrition, vol. 21, no. 2, pp. 207-213, 2005.

[98] A. I. Olives Barba, M. Cámara Hurtado, M. C. Sánchez Mata, V. Fernández Ruiz, and M. López Sáenz de Tejada, "Application of a UV-vis detection-HPLC method for a rapid determination of lycopene and $\beta$-carotene in vegetables," Food Chemistry, vol. 95, no. 2, pp. 328-336, 2006.

[99] E. Reboul, M. Richelle, E. Se Perrot, C. Desmoulins-Malezet, V. Pirisi, and P. Borel, "Bioaccessibility of carotenoids and vitamin E from their main dietary sources," Journal of Agricultural and Food Chemistry, vol. 54, no. 23, pp. 8749-8755, 2006.

[100] A. Shaish, A. Daugherty, F. O'Sullivan, G. Schonfeld, and J. W. Heinecke, "Beta-carotene inhibits atherosclerosis in hypercholesterolemic rabbits," Journal of Clinical Investigation, vol. 96, no. 4, pp. 2075-2082, 1995. 
[101] M. Kataja-Tuomola, J. R. Sundell, S. Männistö et al., "Effect of $\alpha$-tocopherol and $\beta$-carotene supplementation on the incidence of type 2 diabetes," Diabetologia, vol. 51, no. 1, pp. 47-53, 2008.

[102] D. DellaPenna and B. J. Pogson, "Vitamin synthesis in plants: tocopherols and carotenoids," Annual Review of Plant Biology, vol. 57, pp. 711-738, 2006.

[103] G. Giorio, A. Yildirim, A. L. Stigliani, and C. D’Ambrosio, "Elevation of lutein content in tomato: a biochemical tug-of-war between licopene cyclases," Metabolic Engineering, vol. 20, pp. 167-176, 2013.

[104] A. Perry, H. Rasmussen, and E. J. Johnson, "Xanthophyll (lutein, zeaxanthin) content in fruits, vegetables and corn and egg products," Journal of Food Composition and Analysis, vol. 22, no. 1, pp. 9-15, 2009.

[105] J. L. Guil-Guerrero and M. M. Rebolloso-Fuentes, "Nutrient composition and antioxidant activity of eight tomato (Lycopersicon esculentum) varieties," Journal of Food Composition and Analysis, vol. 22, no. 2, pp. 123-129, 2009.

[106] F. Granado, B. Olmedilla, and I. Blanco, "Nutritional and clinical relevance of lutein in human health," British Journal of Nutrition, vol. 90, no. 3, pp. 487-502, 2003.

[107] European Food Safety Authority (EFSA), "Scientific opinion on the substantiation of health claims related to lutein and maintenance of normal vision (ID, 1603, 1604, further assessment) pursuant to Article 13(1) of Regulation (EC) No 1924/2006," The EFSA Journal, vol. 10, no. 6, article 2716, 2012.

[108] E. K. Kabagambe, J. Furtado, A. Baylin, and H. Campos, "Some dietary and adipose tissue carotenoids are associated with the risk of nonfatal acute myocardial infarction in Costa Rica," Journal of Nutrition, vol. 135, no. 7, pp. 1763-1769, 2005.

[109] J. H. Dwyer, M. J. Paul-Labrador, J. Fan, A. M. Shircore, C. N. Bairey Merz, and K. M. Dwyer, "Progression of carotid intimamedia thickness and plasma antioxidants: the Los Angeles atherosclerosis study," Arteriosclerosis, Thrombosis, and Vascular Biology, vol. 24, no. 2, pp. 313-319, 2004.

[110] A. Zanfini, G. Corbini, C. la Rosa, and E. Dreassi, "Antioxidant activity of tomato lipophilic extracts and interactions between carotenoids and $\alpha$-tocopherol in synthetic mixtures," $L W T-$ Food Science and Technology, vol. 43, no. 1, pp. 67-72, 2010.

[111] F. Böhm, R. Edge, E. J. Land, D. J. McGarvey, and T. G. Truscott, "Carotenoids enhance vitamin E antioxidant efficiency," Journal of the American Chemical Society, vol. 119, no. 3, pp. 621-622, 1997.

[112] L. Packer, "Protective role of vitamin E in biological systems," American Journal of Clinical Nutrition, vol. 53, supplement 4, pp. 1050S-1055S, 1991.

[113] S. Liu, I.-M. Lee, Y. Song et al., "Vitamin E and risk of type 2 diabetes in the Women's Health Study randomized controlled trial," Diabetes, vol. 55, no. 10, pp. 2856-2862, 2006.

[114] I.-M. Lee, N. R. Cook, J. M. Gaziano et al., "Vitamin E in the primary prevention of cardiovascular disease and cancer. The women's health study: a randomized controlled trial," Journal of the American Medical Association, vol. 294, no. 1, pp. 56-65, 2005.

[115] E. Paran, V. Novack, Y. N. Engelhard, and I. Hazan-Halevy, "The effects of natural antioxidants from tomato extract in treated but uncontrolled hypertensive patients," Cardiovascular Drugs and Therapy, vol. 23, no. 2, pp. 145-151, 2009.

[116] W. Malewski and P. Markakis, "Ascorbic acid content of the developing tomato fruit," Journal of Food Science, vol. 36, no. 3 , p. $537,1971$.
[117] E. M. Yahia, M. Contreras-Padilla, and G. Gonzalez-Aguilar, "Ascorbic acid content in relation to ascorbic acid oxidase activity and polyamine content in tomato and bell pepper fruits during development, maturation and senescence," LWT-Food Science and Technology, vol. 34, no. 7, pp. 452-457, 2001.

[118] H. E. Sauberlich, "Ascorbic acid," in Present Knowledge in Nutrition, M. L. Brown, Ed., Nutrition Foundation, 1990.

[119] R. E. Olson, "Water soluble vitamins," in Principles of Pharmacology, P. L. Munson, R. A. Mueller, and G. R. Bresse, Eds., chapter 59, Chapman \& Hall, New York, NY, USA, 1999.

[120] K. A. Naidu, "Vitamin C in human health and disease is still a mystery? An overview," Nutrition Journal, vol. 2, article 1, 2003.

[121] S. K. Yogeeta, R. B. R. Hanumantra, A. Gnanapragasam, S. Senthilkumar, R. Subhashini, and T. Devaki, "Attenuation of abnormalities in the lipid metabolism during experimental myocardial infarction induced by isoproterenol in rats: beneficial effect of ferulic acid and ascorbic acid," Basic and Clinical Pharmacology and Toxicology, vol. 98, no. 5, pp. 467-472, 2006.

[122] P. Riso, F. Visioli, D. Erba, G. Testolin, and M. Porrini, "Lycopene and vitamin C concentrations increase in plasma and lymphocytes after tomato intake. Effects on cellular antioxidant protection," European Journal of Clinical Nutrition, vol. 58, no. 10, pp. 1350-1358, 2004.

[123] G. Block, "Vitamin C and cancer prevention: the epidemiological evidence," American Journal of Clinical Nutrition, vol. 53, no. 1, pp. 270S-282S, 1991.

[124] I. D. Coulter, M. L. Hardy, S. C. Morton et al., "Antioxidants vitamin $\mathrm{C}$ and vitamin $\mathrm{E}$ for the prevention and treatment of cancer," Journal of General Internal Medicine, vol. 21, no. 7, pp. 735-744, 2006.

[125] T. Tamura and M. F. Picciano, "Folate and human reproduction," American Journal of Clinical Nutrition, vol. 83, no. 5, pp. 9931016, 2006.

[126] M. D. Iniesta, D. Pérez-Conesa, J. García-Alonso, G. Ros, and M. J. Periago, "Folate content in tomato (Lycopersicon esculentum). Influence of cultivar, ripeness, year of harvest, and pasteurization and storage temperatures," Journal of Agricultural and Food Chemistry, vol. 57, no. 11, pp. 4739-4745, 2009.

[127] T. Forges, P. Monnier-Barbarino, J. M. Alberto, R. M. GuéantRodriguez, J. L. Daval, and J. L. Guéant, "Impact of folate and homocysteine metabolism on human reproductive health," Human Reproduction Update, vol. 13, no. 3, pp. 225-238, 2007.

[128] M. Lucock, "Folic acid: nutritional biochemistry, molecular biology, and role in disease processes," Molecular Genetics and Metabolism, vol. 71, no. 1-2, pp. 121-138, 2000.

[129] C. Wagner, "Biochemical role of folate in cellular metabolism," in Folate in Health and Disease, L. B. Bailey, Ed., pp. 23-42, Marcel Dekker, New York, NY, USA, 1995.

[130] J. Selhub, P. F. Jacques, P. W. F. Wilson, D. Rush, and I. H. Rosenberg, "Vitamin status and intake as primary determinants of homocysteinemia in an elderly population," Journal of the American Medical Association, vol. 270, no. 22, pp. 2693-2698, 1993.

[131] D. G. Hackam and S. S. Anand, "Emerging risk factors for atherosclerotic vascular disease: a critical review of the evidence," Journal of the American Medical Association, vol. 290, no. 7, pp. 932-940, 2003.

[132] A. Splaver, G. A. Lamas, and C. H. Hennekens, "Homocysteine and cardiovascular disease: biological mechanisms, observational epidemiology, and the need for randomized trials," American Heart Journal, vol. 148, no. 1, pp. 34-40, 2004. 
[133] L. Bravo, "Polyphenols: chemistry, dietary sources, metabolism, and nutritional significance," Nutrition Reviews, vol. 56, no. 11, pp. 317-333, 1998.

[134] N. Balasundram, K. Sundram, and S. Samman, "Phenolic compounds in plants and agri-industrial by-products: antioxidant activity, occurrence, and potential uses," Food Chemistry, vol. 99, no. 1, pp. 191-203, 2006.

[135] B. B. Aggarwal and S. Shishodia, "Suppression of the nuclear factor- $\kappa \mathrm{B}$ activation pathway by spice-derived phytochemicals: reasoning for seasoning," Annals of the New York Academy of Sciences, vol. 1030, pp. 434-441, 2004.

[136] I. Rahman, S. K. Biswas, and P. A. Kirkham, "Regulation of inflammation and redox signaling by dietary polyphenols," Biochemical Pharmacology, vol. 72, no. 11, pp. 1439-1452, 2006.

[137] C. R. Caldwell, S. J. Britz, and R. M. Mirecki, "Effect of temperature, elevated carbon dioxide, and drought during seed development on the isoflavone content of dwarf soybean [Glycine max (L.) Merrill] grown in controlled environments," Journal of Agricultural and Food Chemistry, vol. 53, no. 4, pp. 1125-1129, 2005.

[138] D. L. Luthria, S. Mukhopadhyay, and D. T. Krizek, "Content of total phenolics and phenolic acids in tomato (Lycopersicon esculentum Mill.) fruits as influenced by cultivar and solar UV radiation," Journal of Food Composition and Analysis, vol. 19, no. 8, pp. 771-777, 2006.

[139] J. Keijer and E. M. van Schothorst, "Adipose tissue failure and mitochondria as a possible target for improvement by bioactive food components," Current Opinion in Lipidology, vol. 19, no. 1, pp. 4-10, 2008.

[140] Y.-C. Shen, S.-L. Chen, and C.-K. Wang, "Contribution of tomato phenolics to antioxidation and down-regulation of blood lipids," Journal of Agricultural and Food Chemistry, vol. 55, no. 16, pp. 6475-6481, 2007.

[141] M. A. Murcia and M. Martínez-Tomé, "Antioxidant activity of resveratrol compared with common food additives," Journal of Food Protection, vol. 64, no. 3, pp. 379-384, 2001.

[142] A. D’Introno, A. Paradiso, E. Scoditti et al., "Antioxidant and anti-inflammatory properties of tomato fruits synthesizing different amounts of stilbenes," Plant Biotechnology Journal, vol. 7, no. 5, pp. 422-429, 2009.

[143] A. Crozier, M. E. J. Lean, M. S. McDonald, and C. Black, "Quantitative analysis of the flavonoid content of commercial tomatoes, onions, lettuce, and celery," Journal of Agricultural and Food Chemistry, vol. 45, no. 3, pp. 590-595, 1997.

[144] R. Slimestad, T. Fossen, and M. J. Verheul, "The flavonoids of tomatoes," Journal of Agricultural and Food Chemistry, vol. 56, no. 7, pp. 2436-2441, 2008.

[145] M. Rossi, C. Bosetti, E. Negri, P. Lagiou, and C. La Vecchia, "Flavonoids, proanthocyanidins, and cancer risk: a network of case-control studies from Italy," Nutrition and Cancer, vol. 62, no. 7, pp. 871-877, 2010.

[146] B. Shukitt-Hale, W. Kalt, A. N. Carey, M. Vinqvist-Tymchuk, J. McDonald, and J. A. Joseph, "Plum juice, but not dried plum powder, is effective in mitigating cognitive deficits in aged rats," Nutrition, vol. 25, no. 5, pp. 567-573, 2009.

[147] R. Slimestada and M. Verheulb, "Review of flavonoids and other phenolics from fruits of different tomato (Lycopersicon esculentum mill.) cultivars," Journal of the Science of Food and Agriculture, vol. 89, no. 8, pp. 1255-1270, 2009.

[148] J. W. de Bruyn, F. Garretsen, and E. Kooistra, "Variation in taste and chemical composition of the tomato (Lycopersicon esculentumMill.)," Euphytica, vol. 20, no. 2, pp. 214-227, 1971.
[149] I. Martínez-Valverde, M. J. Periago, G. Provan, and A. Chesson, "Phenolic compounds, lycopene and antioxidant activity in commercial varieties of tomato (Lycopersicum esculentum)," Journal of the Science of Food and Agriculture, vol. 82, no. 3, pp. 323-330, 2002.

[150] M. R. Olthof, P. C. H. Hollman, M. N. C. P. Buijsman, J. M. M. van Amelsvoort, and M. B. Katan, "Chlorogenic acid, quercetin3-rutinoside and black tea phenols are extensively metabolized in humans," Journal of Nutrition, vol. 133, pp. 1806-1814, 2003.

[151] M. R. Olthof, P. C. H. Hollman, and M. B. Katan, "Chlorogenic acid and caffeic acid are absorbed in humans," Journal of Nutrition, vol. 131, no. 1, pp. 66-71, 2001.

[152] D. M. Pereira, P. Valentão, J. A. Pereira, and P. B. Andrade, "Phenolics: from chemistry to biology," Molecules, vol. 14, no. 6, pp. 2202-2211, 2009.

[153] A. L. Waterhouse, "Wine phenolics," Annals of the New York Academy of Sciences, vol. 957, pp. 21-36, 2002.

[154] B. A. Fox and A. G. Cameron, Food Science, Nutrition \& Health, chapter 13, Vitamins. J.W. Arrowsmith, Bristol, UK, 6th edition, 1995.

[155] K. H. van Het Hof, C. E. West, J. A. Weststrate, and J. G. A. J. Hautvast, "Dietary factors that affect the bioavailability of carotenoids," Journal of Nutrition, vol. 130, no. 3, pp. 503-506, 2000.

[156] M. W. Davey, M. van Montagu, D. Inzé et al., "Plant Lascorbic acid: chemistry, function, metabolism, bioavailability and effects of processing," Journal of the Science of Food and Agriculture, vol. 80, no. 7, pp. 825-860, 2000.

[157] C. Gärtner, W. Stahl, and H. Sies, "Lycopene is more bioavailable from tomato paste than from fresh tomatoes," American Journal of Clinical Nutrition, vol. 66, no. 1, pp. 116-122, 1997.

[158] D. Veronica, W. Xianzhong, K. K. Adom, and R. H. Liu, "Thermal processing enhances the nutritional value of tomatoes by increasing total antioxidant activity," Journal of Agricultural and Food Chemistry, vol. 50, no. 10, pp. 3010-3014, 2002.

[159] I. Colle, L. Lemmens, S. van Buggenhout, A. van Loey, and M. Hendrickx, "Effect of thermal processing on the degradation, isomerization, and bioaccessibility of lycopene in tomato pulp," Journal of Food Science, vol. 75, no. 9, pp. C753-C759, 2010.

[160] I. J. P. Colle, A. Andrys, A. Grundelius et al., "Effect of pilot-scale aseptic processing on tomato soup quality parameters," Journal of Food Science, vol. 76, no. 5, pp. C714-C723, 2011.

[161] S. Gahler, K. Otto, and V. Böhm, "Alterations of vitamin C, total phenolics, and antioxidant capacity as affected by processing tomatoes to different products," Journal of Agricultural and Food Chemistry, vol. 51, no. 27, pp. 7962-7968, 2003.

[162] C. Seybold, K. Fröhlich, R. Bitsch, K. Otto, and V. Böhm, "Changes in contents of carotenoids and vitamin E during tomato processing," Journal of Agricultural and Food Chemistry, vol. 52, no. 23, pp. 7005-7010, 2004.

[163] C.-H. Chang, H.-Y. Lin, C.-Y. Chang, and Y.-C. Liu, "Comparisons on the antioxidant properties of fresh, freeze-dried and hot-air-dried tomatoes," Journal of Food Engineering, vol. 77, no. 3, pp. 478-485, 2006.

[164] A. Patras, N. P. Brunton, C. O'Donnell, and B. K. Tiwari, "Effect of thermal processing on anthocyanin stability in foods; mechanisms and kinetics of degradation," Trends in Food Science and Technology, vol. 21, no. 1, pp. 3-11, 2010.

[165] C. Martin, "The interface between plant metabolic engineering and human health," Current Opinion in Biotechnology, vol. 24, no. 2, pp. 344-353, 2013. 
[166] C. Zhu, G. Sanahuja, D. Yuan et al., "Biofortification of plants with altered antioxidant content and composition: genetic engineering strategies," Plant Biotechnology Journal, vol. 11, no. 2, pp. 129-141, 2013.

[167] C. Zhang, J. Liu, Y. Zhang et al., "Overexpression of SlGMEs leads to ascorbate accumulation with enhanced oxidative stress, cold, and salt tolerance in tomato," Plant Cell Reports, vol. 30, no. 3, pp. 389-398, 2011.

[168] V. M. Haroldsen, C. L. Chi-Ham, S. Kulkarni, A. Lorence, and A. B. Bennett, "Constitutively expressed DHAR and MDHAR influence fruit, but not foliar ascorbate levels in tomato," Plant Physiology and Biochemistry, vol. 49, no. 10, pp. 1244-1249, 2011.

[169] S. Römer, P. D. Fraser, J. W. Kiano et al., "Elevation of the provitamin A content of transgenic tomato plants," Nature Biotechnology, vol. 18, no. 6, pp. 666-669, 2000.

[170] C. Cronje, G. M. George, A. R. Fernie, J. Bekker, J. Kossmann, and R. Bauer, "Manipulation of 1-ascorbic acid biosynthesis pathways in Solanum lycopersicum: elevated GDP-mannose pyrophosphorylase activity enhances l-ascorbate levels in red fruit," Planta, vol. 235, no. 3, pp. 553-564, 2012.

[171] R. I. Díaz de la Garza, J. F. Gregory III, and A. D. Hanson, "Folate biofortification of tomato fruit," Proceedings of the National Academy of Sciences of the United States of America, vol. 104, no. 10, pp. 4218-4222, 2007.

[172] R. Díaz de la Garza, E. P. Quinlivan, S. M. J. Klaus, G. J. C. Basset, J. F. Gregory III, and A. D. Hanson, "Folate biofortification in tomatoes by engineering the pteridine branch of folate synthesis," Proceedings of the National Academy of Sciences of the United States of America, vol. 101, no. 38, pp. 13720-13725, 2004.

[173] T. Hossain, I. Rosenberg, J. Selhub, G. Kishore, R. Beachy, and K. Schubert, "Enhancement of folates in plants through metabolic engineering," Proceedings of the National Academy of Sciences of the United States of America, vol. 101, no. 14, pp. 5158-5163, 2004.

[174] W. Apel and R. Bock, "Enhancement of carotenoid biosynthesis in transplastomic tomatoes by induced lycopene-to-provitamin a conversion," Plant Physiology, vol. 151, no. 1, pp. 59-66, 2009.

[175] G. Giovinazzo, L. D’Amico, A. Paradiso, R. Bollini, F. Sparvoli, and L. DeGara, "Antioxidant metabolite profiles in tomato fruit constitutively expressing the grapevine stilbene synthase gene," Plant Biotechnology Journal, vol. 3, no. 1, pp. 57-69, 2005.

[176] G. R. Davuluri, A. van Tuinen, P. D. Fraser et al., "Fruit-specific RNAi-mediated suppression of DET1 enhances carotenoid and flavonoid content in tomatoes," Nature Biotechnology, vol. 23, no. 7, pp. 890-895, 2005.

[177] E. Butelli, L. Titta, M. Giorgio et al., "Enrichment of tomato fruit with health-promoting anthocyanins by expression of select transcription factors," Nature Biotechnology, vol. 26, no. 11, pp. 1301-1308, 2008.

[178] A. Mazzucato, R. Papa, E. Bitocchi et al., "Genetic diversity, structure and marker-trait associations in a collection of Italian tomato (Solanum lycopersicum L.) landraces," Theoretical and Applied Genetics, vol. 116, no. 5, pp. 657-669, 2008.

[179] M. P. Kinkade and M. R. Foolad, "Validation and fine mapping of lyc12.1, a QTL for increased tomato fruit lycopene content," Theoretical and Applied Genetics, vol. 126, no. 8, pp. 2163-2175, 2013.

[180] Y. D. Sun, Y. Liang, J. M. Wu, Y. Z. Li, X. Cui, and L. Qin, "Dynamic QTL analysis for fruit lycopene content and total soluble solid content in a Solanum lycopersicum x S. pimpinellifolium cross," Genetics and Molecular Research, vol. 11, no. 4, pp. 3696-3710, 2012.
[181] A. di Matteo, A. Sacco, M. Anacleria et al., "The ascorbic acid content in tomato fruits is associated with the expression of genes involved in pectin degradation," BMC Plant Biology, vol. 10, article 163, 2010.

[182] A. di Matteo, A. Sacco, V. Ruggieri, N. Trotta, A. Nunziata, and A. Barone, "Transcriptional network controlling antioxidants in tomato fruit," Journal of Biotechnology, vol. 150, pp. 111-112, 2010.

[183] A. Sacco, A. di Matteo, N. Lombardi et al., "Quantitative trait loci pyramiding for fruit quality traits in tomato," Molecular Breeding, vol. 31, no. 1, pp. 217-222, 2013.

[184] J. Luo, E. Butelli, L. Hill et al., "AtMYB12 regulates caffeoyl quinic acid and flavonol synthesis in tomato: expression in fruit results in very high levels of both types of polyphenol," Plant Journal, vol. 56, no. 2, pp. 316-326, 2008.

[185] A. Bovy, R. de Vos, M. Kemper et al., "High-flavonol tomatoes resulting from the heterologous expression of the maize transcription factor genes LC and C1," Plant Cell, vol. 14, no. 10, pp. 2509-2526, 2002.

[186] J. Xu, N. Ranc, S. Muños et al., "Phenotypic diversity and association mapping for fruit quality traits in cultivated tomato and related species," Theoretical and Applied Genetics, vol. 126, no. 3, pp. 567-581, 2013.

[187] N. Schauer, Y. Semel, U. Roessner et al., "Comprehensive metabolic profiling and phenotyping of interspecific introgression lines for tomato improvement," Nature Biotechnology, vol. 24, no. 4, pp. 447-454, 2006.

[188] L. A. Mueller, S. D. Tanskley, J. J. Giovannoni et al., "The tomato sequencing project, the first cornerstone of the International Solanaceae Project (SOL)," Comparative and Functional Genomics, vol. 6, no. 3, pp. 153-158, 2005.

[189] S. Sato, S. Tabata, H. Hirakawa et al., "The tomato genome sequence provides insights into fleshy fruit evolution," Nature, vol. 485, pp. 635-641, 2012.

[190] X. Li, H. Sun, J. Pei et al., "De novo sequencing and comparative analysis of the blueberry transcriptome to discover putative genes related to antioxidants," Gene, vol. 511, no. 1, pp. 54-61, 2012. 


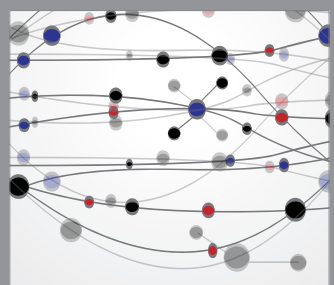

The Scientific World Journal
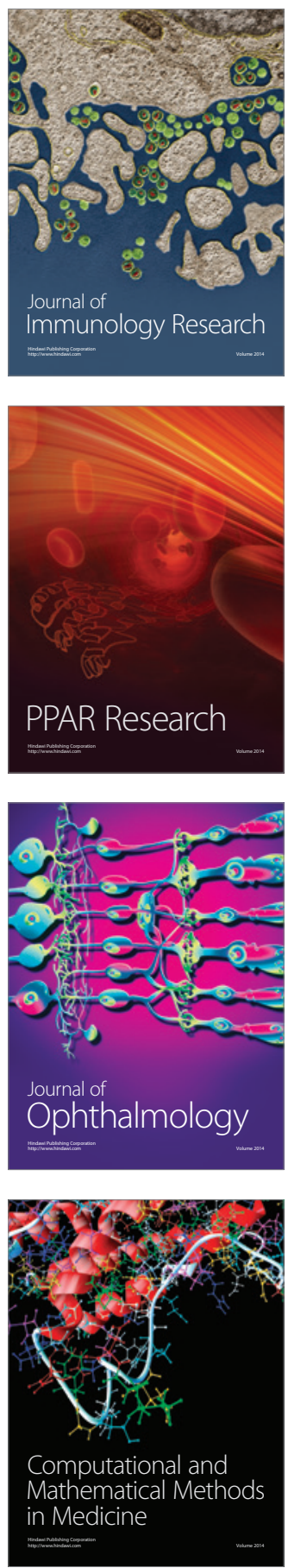

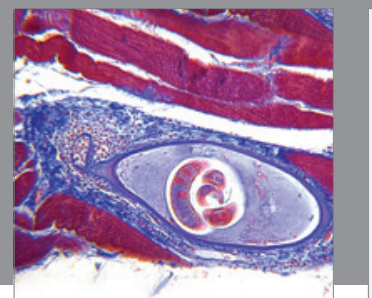

Gastroenterology

Research and Practice
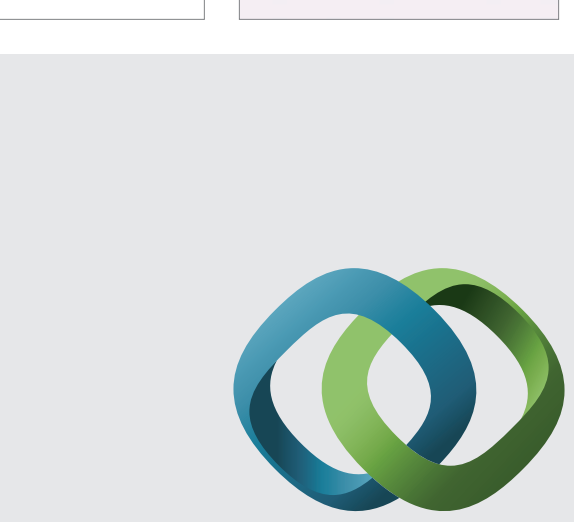

\section{Hindawi}

Submit your manuscripts at

http://www.hindawi.com
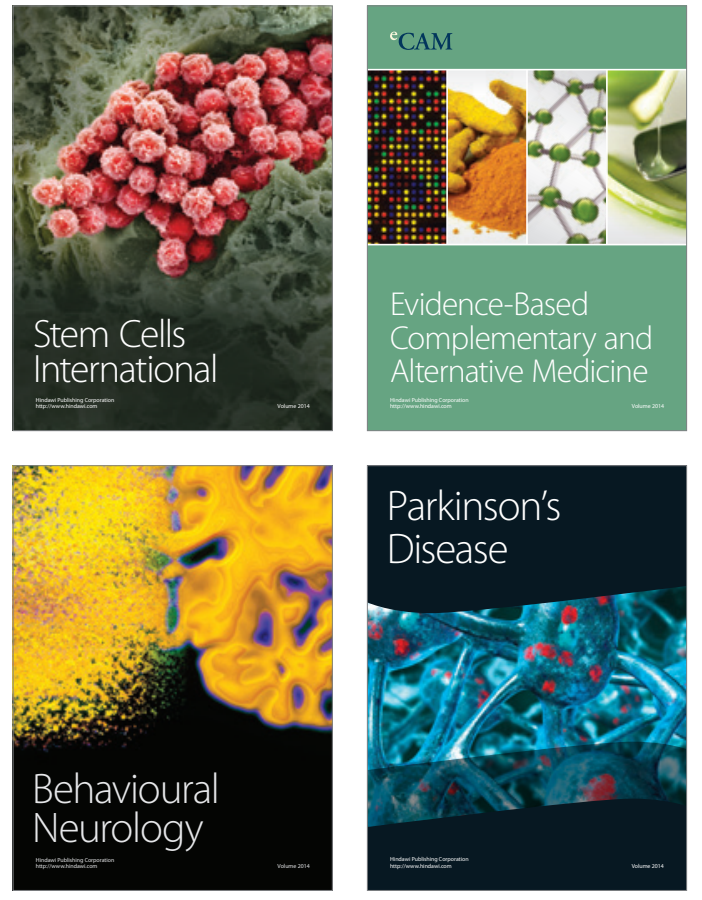
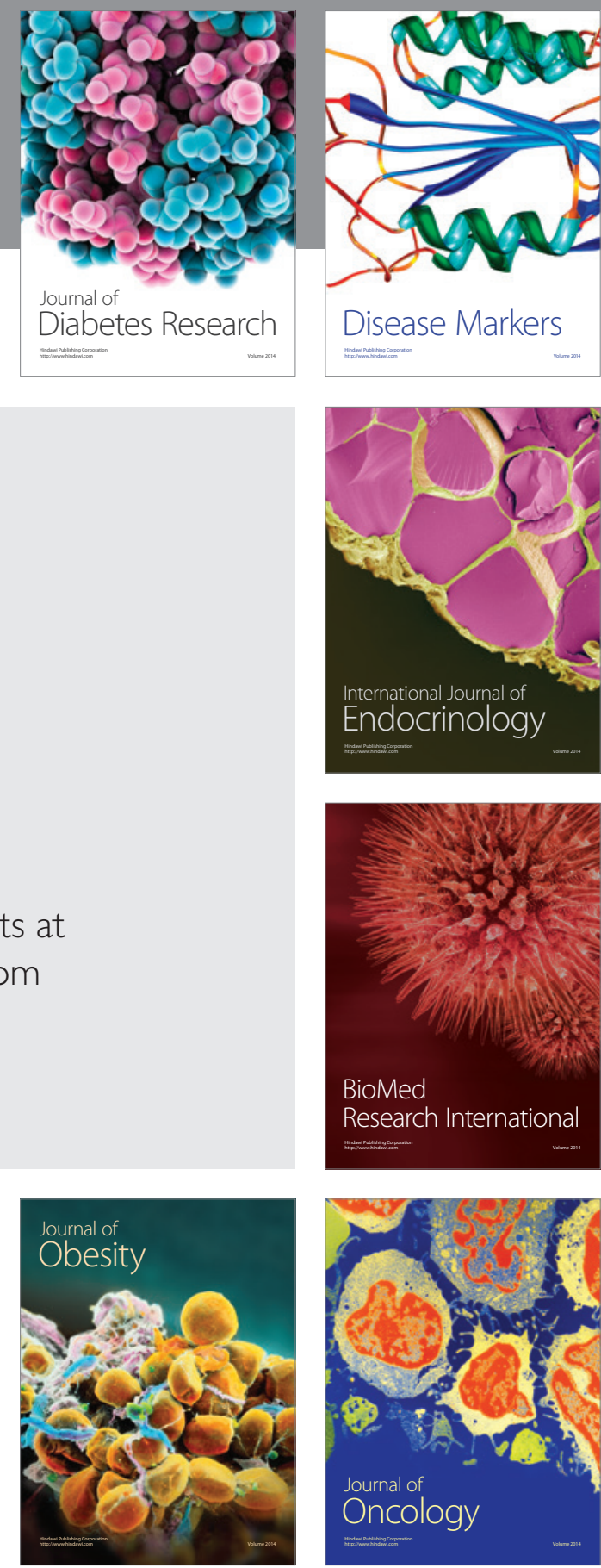

Disease Markers
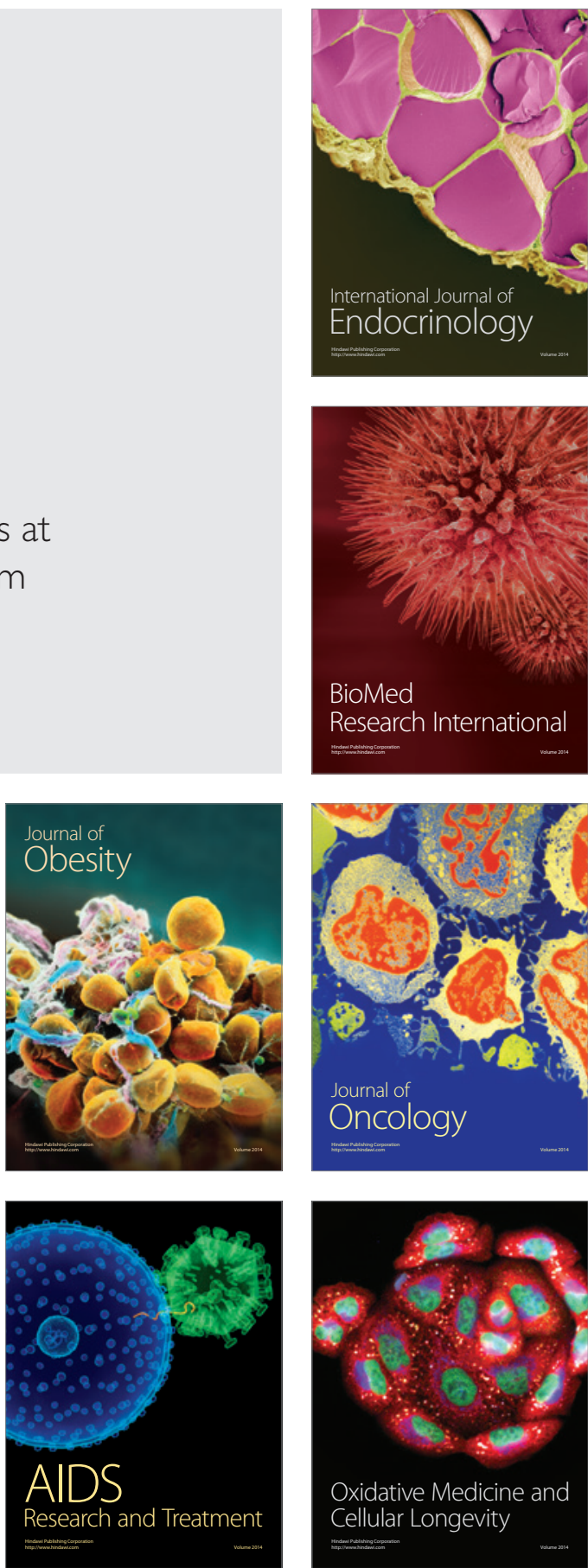